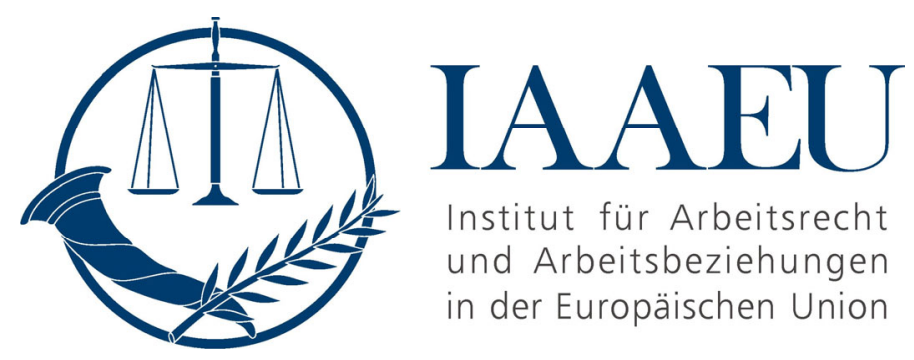

IAAEU Discussion Paper Series in Economics No. $01 / 2020$

\title{
Thorstein Veblen, Joan Robinson, and George Stigler (probably) never met: Social Preferences, Monopsony, and Government Intervention
}

\section{Laszlo Goerke, Michael Neugart}

\section{January 2020}

Institute for Labour Law and Industrial Relations in the European Union (IAAEU)

54296 Trier

www.iaaeu.de 


\title{
Thorstein Veblen, Joan Robinson, and George Stigler \\ (probably) never met: Social Preferences, Monopsony, and
}

\author{
Government Intervention*
}

\author{
Laszlo Goerke ${ }^{\dagger}$ and Michael Neugart ${ }^{\ddagger}$
}

January 23,2020

\begin{abstract}
Wages and employment are too low in a monopsony. Furthermore, a minimum wage or a subsidy may raise employment up to its first-best level. First, we analyze whether these important predictions still hold if workers compare their income to that of a reference group. Second, we show that the undistorted, competitive outcome may no longer constitute the benchmark for welfare comparisons. Third, we derive a condition which guarantees that the monopsony distortion is exactly balanced by the impact of social comparisons. Finally, we show how wage restrictions and subsidies or taxes can be used to ensure this condition both for a welfarist and a paternalistic welfare objective.
\end{abstract}

Keywords: social preferences, government intervention, minimum wage, monopsony, taxation, wage regulation

JEL-classification: D10, H21, J30, J42

${ }^{*}$ We are grateful for helpful comments by Ronald Bachmann, Leif Danziger, Marco de Pinto and Fabian Kindermann, as well as participants of the the 33rd Annual Conference of the Italian Association of Labour Economics (AIEL) in Ancona, the annual meeting of the Standing Field Committee for Population Economics of the Verein für Socialpolitik (VfS) in Würzburg, the 2019 International Conference on Public Economic Theory (PET) in Strasbourg, the Asian and Australasian Society of Labour Economics (AASLE) meeting in Singapore, and members of the ZiF (Center of Interdisciplinary Research, Bielefeld) research group "In Search of the Global Labour Market: Actors, Structures, and Policies", of which the second author was an associate member from October 2017 until July 2018.

${ }^{\dagger}$ Universität Trier, IAAEU (Institut für Arbeitsrecht und Arbeitsbeziehungen in der Europäischen Union), Campus II, D-54286 Trier, Germany, IZA, Bonn, CESifo, München, E-mail: goerke@iaaeu.de

${ }^{\ddagger}$ Technische Universität Darmstadt, Department of Law and Economics, Hochschulstraße 1, D-64289 Darmstadt, Germany, E-mail: neugart@vwl.tu-darmstadt.de 


\section{Introduction}

In standard textbook settings individual consumption and labor supply decisions are usually guided by own endowments only. There is, however, ample evidence that questions this assumption (see, e.g., Neumark and Postlewaite, 1998; Bowles and Park, 2005; Frank, 2008; Park, 2010). Individual decisions are often and substantially influenced by relative or positional considerations. Accordingly, an extensive literature has developed which analyzes the impact of preferences featuring social comparisons on competitive labor market outcomes. However, labor markets very often do not correspond to this setting and may more adequately be characterized as imperfectly competitive. Empirically, it has been shown that a firm's labor supply is not infinitely elastic, see, e.g., Nelson (1973) and Sullivan (1989) for pioneering work. These and also more recent findings ${ }^{1}$ suggest that monopsonies are a pertinent feature of many labor markets. Moreover, they have arguably become more important in recent years, due to an increasing concentration of sales among firms with superior products that allows them to control larger market shares (see, e.g., Autor et al., 2017). Similarly, social media, such as Facebook or Instagram, have enhanced the scope for social comparisons. Therefore, it is astonishing that these highly pervasive facts, the prevalence of monopsonistic labor markets and of social comparisons, have only been looked at in isolation, instead of constituting the empirical basis for a theoretical analysis of market outcomes and their policy implications.

In this paper, we investigate what happens if the two distortions - monopsony and externalities due to social comparisons - interact. In particular, we are interested in exploring their wage and employment effects. Subsequently, we adopt a normative perspective and characterize the efficient employment level both for a welfarist and a paternalistic objective. Additionally, we consider how policy instruments commonly used to correct either monopsony power or consumption externalities, such as minimum wages or taxes, can be employed in

\footnotetext{
${ }^{1}$ Azar et al. (2018) employ online vacancy posting and infer that about half of all labor markets in the United States are highly concentrated according to the definition of the Federal Trade Commission in its merger guidelines and may, thus, be regarded as exhibiting features of a monopsony. Moreover, the relevance of monopsonistic labor markets is likely to rise in the future, when the standard employment relation is increasingly being replaced by more flexible forms of contracts. For the extreme form of this flexibility, crowdworking, Dube et al. (2020) estimate labor supply elasticities for one of the largest on-demand platforms of around 0.1. More recent evidence is also included in the meta study on monopsony power by Sokolova and Sorensen (2018).
} 
order to achieve efficiency.

The ingredients of our analyses each have a long tradition in economics. Thorstein Veblen already asserted more than 100 years ago that "Relative success, tested by an invidious pecuniary comparison with other men, becomes the conventional end of action." (Veblen, 1899, ch. 2: Pecuniary emulation, p. 24). ${ }^{2}$ Monopsony and the effects of an upward sloping labor supply curve to the firm were analyzed by Joan Robinson in the 1930s (Robinson, 1933, ch. 18), and the (de-) merits of minimum wages were discussed as early as in the 1940s by George J. Stigler (Stigler, 1946). Nonetheless, the analyses of the various concepts have, to the best of our knowledge, not been combined. Given that Joan Robinson was born in 1903, while Thorstein Veblen died in 1929, and taking into account, for example, George J. Stigler's derogatory review of Robinson's book entitled Economic Philosophy (Stigler, 1963), it seems unlikely that our figureheads have ever met to discuss their ideas.

As is well known, in a monopsony there is insufficient employment in the absence of social comparisons, and wages are lower than on a competitive market, because the firm's marginal employment costs exceed the wage. In consequence, a minimum wage can raise employment and welfare (see, e.g., Manning, 2003). In contrast, social comparisons featuring jealousy result in excessive employment in a competitive labor market, while wages will be lower than in the absence of such preferences. The reason is that individuals have an incentive to expand labor supply in order to raise income and thereby improve their relative position. Since such relative concerns give rise to externalities, welfare can be increased if labor supply is curtailed. Accordingly, relative or positional considerations can justify progressive income taxation in competitive markets (see, e.g., Persson, 1995; Ireland, 2001; Corneo, 2002; Aronsson and Johansson-Stenman, 2014, 2015), or the use of wage ceilings.

Our analysis, first, shows that the impact of social comparisons on wages and employment is ambiguous in monopsony. The direction of the effects largely depends on how social comparisons affect the labor supply elasticity to the firm directly, and indirectly through changes of wages and employment. Jealousy shifts the labor supply curve downwards in the

\footnotetext{
${ }^{2}$ Other very early contributions to the role of social preferences for individual choices include Smith (1776, Book V, Ch. II, Part 2), Pigou (1903, p. 60), Keynes (1936, ch. 2) and also Marx (1977).
} 
wage-employment space, and also affects its slope. In consequence, social comparisons do not necessarily shift the monopsonist's marginal cost curve downward, as well. Thus, predicting the wage and employment impact requires restrictions relating to the labor supply elasticity.

Second, a welfarist social planner confronted with the two distortions, a monopsony and externalities due to social comparisons, will not always prefer an employment level that equals the one which occurs on a competitive market without social comparisons. Social comparisons are preference-based and cause externalities. The social planner internalizes these externalities when determining optimal employment. However, internalization is not generally equivalent to the absence of social preferences, as the latter affect the marginal utility from consumption. Accordingly, the first-best outcome in the presence of social comparisons will only equal the competitive one in their absence if workers' marginal utility satisfies rather special properties. Our analysis clarifies that an outcome in which the net effect of the two distortions is zero only constitutes the benchmark for a welfarist policy for special utility functions.

Our third set of findings relates to policy instruments. Assuming that the welfarist social planner uses wages in order to achieve her desired employment level, we find that she will impose a minimum wage if the labor supply elasticity is sufficiently small, relative to the intensity of social comparisons. Otherwise, it would be optimal to set a maximum wage or wage cap. A minimum wage, as is well established, would reduce marginal employment costs, thus expanding employment. A wage cap would prevent the monopsonist from raising employment beyond the (welfare-maximizing) level. Analogously to the wage regulation, we can also determine optimal tax rates or subsidies to restore efficiency. This also depends on the magnitude of the labor supply elasticity relative to the strength of social comparisons. These findings are qualitatively unaffected by modifications of the social planner's objective.

While there is sweeping work on monopsonistic labor markets (Manning, 2003) and widespread interest in the effects of social preferences on market outcomes (see, among others, Persson, 1995; Ireland, 2001; Corneo, 2002; Liu and Turnovsky, 2005; Aronsson and JohanssonStenman, 2008, 2014, 2015, 2018; Wendner and Goulder, 2008; Mujcic and Frijters, 2015), our contribution sits well with a less developed literature that looks into market outcomes 
when these two distortions meet. Desiraju and Sappington (2007) and von Siemens (2010; 2012) study the impact of social comparisons in a monopsony. Contrary to our contribution, they are interested in workers' sorting behavior into particular jobs, when they have private information relating to their ability or social preferences. In previous work (Goerke and Neugart, 2017), we analyze social comparisons in oligopsony in which heterogeneous firms have limited market power and compete for the same pool of labor. We show for this framework, based on the set-up by Salop (1979), that a stronger prevalence of wage comparisons decreases wage inequality, shifts the functional income distribution in favor of workers, and increases welfare. In the Salop-type model, social comparisons unambiguously raise the labor supply elasticity, such that a crucial element of the present analysis is without impact. Accordingly, we deviate from Goerke and Neugart (2017) by deriving the effects of social comparisons for a monospsony and by demonstrating that the exact nature of the firms' market power affects outcomes. Moreover, and in contrast to Goerke and Neugart (2017), we scrutinize the suitability of various policy instruments to remedy the welfare losses resulting from the interaction of social comparisons and market power by employers for alternative welfare definitions. Finally, Sandmo (1994) studies a two-part wage schedule in monopsony. He shows that the monopsonist will equalize the effort-related wage component and a worker's marginal productivity and use the fixed income component to raise profits at the expense of wage income. These benefits of second-degree price discrimination extend to a setting in which individuals exhibit social comparisons. Consequently, in Sandmo (1994) there is no interaction between the two distortions we consider.

Market power may not only originate on the demand side of the labor market. Employees can also influence market outcomes. Goerke and Hillesheim (2013) show that labor demand and actual hours of work decline in a labor market with firm-specific trade unions, which represent individuals with preferences featuring social comparisons. The reason is that unions can internalize the impact of social comparisons that would otherwise have led to excessive work. Chang et al. (2018) developed the same basic idea independently. They also derive the potential for a welfare-enhancing role of trade unions in the presence of social comparisons and 
calculate a critical value for the union's bargaining power, such that the preference externality is fully internalized by the labor market distortion. Furthermore, Mauleon et al. (2014) investigate how strike activity by a trade union, whose members have social preferences, changes with the structure of the market on which the firm sells its products. Finally, interactions of social comparisons with some sort of market power are also studied outside of the labor market context (Woo 2011; 2016 ; Guo, 2005), emphasizing the relevance of the setting we consider.

In the next section, we describe our analytical apparatus. In Section 3, we show how social comparisons affect the market outcome if the labor market is characterized by a monopsony, focusing on the case of jealousy. Subsequent to this positive analysis, we characterize optimal employment from a welfarist perspective in the presence of two distortions: monopsony and externalities resulting from social comparisons. We also show how wage regulations, via either minimum or maximum remuneration levels (Section 4.2), and taxes and subsidies (Section 4.3) can be employed to enforce the optimal employment level. In Section 5, we assume that it is not jealousy but admiration that constitutes the externality. In order to scrutinize the robustness of our findings with respect to the welfare definition, we consider a paternalistic social planner in Section 6. We conclude in Section 7.

\section{The Model}

\subsection{General Set-up}

We consider a world in which a monopsonist employs a large number of individuals. These workers derive utility from their own consumption and exhibit social preferences, since utility depends on a reference level, as well. From the perspective of an individual worker, reference consumption is exogenous. This kind of Nash-behavior implies that each individual creates an externality when deciding about labor supply and, hence, neglects the impact of own consumption on other individuals. Because these distortions already arise in a world with homogeneous individuals, we assume that all workers are identical also ex-post. In consequence, all workers are employed by the monopsonist and variations in employment take place at the intensive 
margin. This simplification does not substantially affect predictions and allows us to define welfare in a straightforward manner because we do not have to compare payoffs across individuals. In contrast to workers, the monopsonist can take into account that a wage change will alter not only consumption of each employee, but also the reference level and, hence, correctly anticipates the labor supply effects of altering the wage (Sandmo, 1994). Therefore, the monopsonist can partially internalize the externalities due to social preferences which, for example, is not feasible in oligopsony. This is the case because wages of competitors and, hence, reference income, are given from the perspective of each oligopsonistic firm (Goerke and Neugart, 2017).

The monopsonist can sell its output at a fixed price normalized to unity, for example, on an internationally integrated market. Therefore, income changes do not have an impact on product and labor demand. Workers are paid a wage, $w$, and supply an amount of labor, $L$, resulting in labor income, $w L$. In addition, profits are redirected to workers. Accordingly, the functional income distribution is without impact and we can concentrate on efficiency consequences of social comparisons in the normative part of our analysis. Workers are pricetakers and, hence, cannot influence the wage, $w$. Moreover, they view the level of profit income, $\pi$, as given and, thus, as unaffected by labor supply decisions. This assumption and the differential ability of the monopsonist and an individual worker to affect reference consumption reflect the idea that the firm has market power, while each individual's actions have negligible effects on market outcomes.

\subsection{Preferences}

A worker's utility, $U$, increases in own consumption, $c$, at a decreasing rate and decreases in working time, $L$, at a weakly increasing rate, such that

$$
U=U\left(c, c^{r}, \gamma, L\right)
$$

and $U_{c c}, U_{L}<0<U_{c}$ and $U_{L L} \leq 0$ hold, where subscripts denote partial derivatives. More-

over, utility varies with consumption of a reference group, $c^{r}$. In previous empirical contri- 
butions, various kinds of reference groups have been looked at, such as neighbors, parents, people who are comparable with respect to age, education etc., individuals who have the same occupation, or colleagues (Luttmer, 2005; Senik, 2009; Goerke and Pannenberg, 2015; Clark et al., 2017). Given our setting, we focus on colleagues. Moreover, we primarily consider the case of jealousy, as defined by Dupor and Liu (2003), such that $U_{c^{r}}<0$ holds. Accordingly, our model is set up in such a way that the employment-reducing impact of monopsony power could be counteracted by the employment-enhancing effect of social comparisons (see, e.g., Frank, 1984; Schor, 1991; Dupor and Liu, 2003). Most of our findings also apply if individuals exhibit admiration of colleagues $\left(U_{c^{r}}>0\right)$, as we show in Section 5. Finally, the parameter $\gamma, 0 \leq \gamma$, indicates the intensity with which employees compare their consumption to that of the reference group. If, for example, social preferences are of the additive type (Clark and Oswald, 1998), and we consider jealousy, we could specify utility as $U=U\left(c-\gamma c^{r}, L\right)$. The additive, or subtractive, specification is often distinguished from a multiplicative formulation of preferences (Carroll, 2000), in which the ratio of own to reference consumption determines utility, such that $U\left(c /\left(c^{r}\right)^{\gamma}, L\right)$ holds. For both specifications, the signs of $U_{\gamma}$ and $U_{c^{r}}$, as well of $U_{c \gamma}$ and $U_{c c^{r}}$, coincide. Nonetheless, the distinction between $\gamma$ and $c^{r}$ is analytically helpful, because it allows us to vary the intensity, $\gamma$, of social comparisons exogenously, whereas reference consumption, $c^{r}$, is determined endogenously.

As in Persson (1995), Corneo (2002), or Goerke and Hillesheim (2013), among others, we assume that utility is separable in consumption and labor supply $\left(U_{c L}=U_{c^{r} L}=0\right)$. In our context, this restriction enables us to unambiguously determine the impact of higher wages and more intense social comparisons on labor supply. Moreover, the constraint implies that jealousy is equivalent to Keeping-up-with-the-Joneses (KUJ) preferences, which are empirically validated in a series of studies, see, e.g., Clark and Oswald (1996), Blanchflower and Oswald (2004), Ferrer-i Carbonell (2005), Luttmer (2005), or Senik (2009). Because we have no robust empirical evidence on the impact of less leisure on the marginal utility from own consumption or consumption by the reference group, we will also briefly consider the implications of the separability assumption at appropriate instances below. 
Dupor and Liu (2003), inter alia, define KUJ preferences as a situation in which the marginal rate of substitution between leisure and consumption increases with the reference level of consumption $c^{r}$. With additively separable preferences this implies $U_{c c^{r}}>0$ (which we subsequently assume to be the case). That is, an increase in reference consumption increases the marginal utility from own consumption. Finally, we assume that the direct positive impact of a general increase in consumption dominates the indirect one via reference consumption. This holds both for the utility level, U, (Dupor and Liu, 2003) and the marginal utility from consumption, $U_{c}$ (Liu and Turnovsky, 2005), implying that $U_{c}+U_{c^{r}}>0>U_{c c}+U_{c c^{r}}$ for $d c$ $=d c^{r}>0$. These restrictions, for example, ensure that the aggregate labor supply curve is upward sloping.

\subsection{Labor Supply}

Individual labor supply: To reduce notational burden, we set the number of workers equal to one. The representative worker chooses working hours or labor supply to maximize utility subject to the budget constraint, $c=w L+\pi$. Since each worker regards profits $\pi$ as fixed, the first-order condition for a utility maximum is:

$$
\frac{d U\left(c, c^{r}, L\right)}{d L}=U_{c}\left(c, c^{r}, \gamma\right) w+U_{L}(L)=0
$$

Given the separability assumption, marginal utility from consumption does not depend on working time directly, $U_{c}=U_{c}\left(c, c^{r}, \gamma\right)$, whereas the marginal disutility from working is independent of consumption levels, $U_{L}=U_{L}(L)$. Accordingly, individual labor supply, $\hat{L}$, is increasing in the wage, $w$, if the direct substitution effect dominates the income effect.

$$
\frac{d \hat{L}}{d w}=-\frac{\frac{d^{2} U\left(c, c^{r}, L\right)}{d L d w}}{\frac{d^{2} U\left(c, c^{r}, L\right)}{d L^{2}}}=-\frac{U_{c}+U_{c c} w L}{U_{c c} w^{2}+U_{L L}}
$$

Aggregate labor supply: Next, we consider the consequences of a higher wage paid by the 
monopsonist on labor supply, that is, of an encompassing wage increase. In order to determine this impact, we have to incorporate not only the effect on own consumption, $\partial c / \partial w=L$, but also the repercussion on the reference level, $\partial c^{r} / \partial w$, which will be positive if it is also financed by labor income. Moreover, the reference group will also adjust labor supply. Holding constant profits, the change in aggregate labor supply can be derived from:

$$
U_{c}\left(c(w, L), c^{r}(w, L), \gamma\right) w+U_{L}(L)=0
$$

Totally differentiating the above expression for $c=w L+\pi$ yields the slope of the aggregate labor supply curve :

$$
\frac{d L}{d w}=-\frac{\frac{d\left(U_{c}\left(c, c^{r}, \gamma\right) w+U_{L}(L)\right)}{d w}}{\frac{d\left(U_{c}\left(c, c^{r}, \gamma\right) w+U_{L}(L)\right)}{d L}}=-\frac{U_{c}+w\left(U_{c c} L+U_{c c^{r}} \frac{\partial c^{r}}{\partial w}\right)}{w\left(U_{c c} w+U_{c c^{r}} \frac{\partial c^{r}}{\partial L}\right)+U_{L L}} .
$$

We can simplify expression (5) if we explicitly incorporate the assumption of homogeneous workers, which implies that reference consumption equals own consumption $\left(c=c^{r}\right)$, and the feature that the monopsonist takes into account that workers obtain profit income. As there are no costs other than wages, and denoting the production function by $f(L)$, profits can be written as: $\pi=f(L)-w L$. It follows that consumption equals $c=c^{r}=w L+\pi=w L+f(L)-w L=$ $f(L)$. In addition, we have $\partial c^{r} / \partial w=\partial c / \partial w=0$ and $\partial c^{r} / \partial L=\partial c / \partial L=f^{\prime}(L)$, so that the slope of the aggregate labor supply curve (5) becomes

$$
L_{w}=-\frac{U_{c}}{w\left(U_{c c}+U_{c c^{r}}\right) f^{\prime}(L)+U_{L L}}>0 .
$$

Hence, the aggregate labor supply curve only reflects the substitution effect of a wage increase, but no income effect anymore. Moreover, an increase in the importance of reference consumption raises aggregate labor supply, $L=L(w, \gamma)$, in the presence of KUJ preferences, as $U_{c \gamma}$ and $U_{c c^{r}}$ are positive.

$$
L_{\gamma}=-\frac{U_{c \gamma} w}{w\left(U_{c c}+U_{c c^{r}}\right) f^{\prime}(L)+U_{L L}}>0 .
$$




\subsection{Wage Choice}

The production function $f(L)$, is characterized by standard properties, that is, $f(0)=0$, $f^{\prime}(0) \rightarrow \infty$, and $f^{\prime}>0, f^{\prime \prime}<0$ for $L>0$. The monopsonist maximizes profits by setting the wage, taking into account the impact on aggregate labor supply (as described in (6)):

$$
\pi=f(L(w, \gamma))-w L(w, \gamma)
$$

The first-order condition for a profit-maximizing choice can, using the definition of the (aggregate) wage elasticity of labor supply, $\epsilon(w, L(w, \gamma), \gamma)=L_{w} w / L>0$, be expressed as:

$$
\pi_{w}=f^{\prime}(L) L_{w}-L-w L_{w}=\frac{L(w, \gamma) \epsilon(w, L(w, \gamma), \gamma)}{w}\left[f^{\prime}(L)-w \frac{1+\epsilon(w, L(w, \gamma), \gamma)}{\epsilon(w, L(w, \gamma), \gamma)}\right]=0
$$

The monopsonist will set a wage equal to the marginal product of labor, corrected by a factor that depends on the labor supply elasticity. The second-order condition is:

$$
\begin{gathered}
\pi_{w w}=\frac{L(w, \gamma) \epsilon(w, L(w, \gamma), \gamma)}{w} \\
{\left[f^{\prime \prime}(L) L_{w}-\frac{1+\epsilon(w, L(w, \gamma), \gamma)}{\epsilon(w, L(w, \gamma), \gamma)}+\frac{w}{(\epsilon(w, L(w, \gamma), \gamma))^{2}} \frac{d \epsilon(w, L(w, \gamma), \gamma)}{d w}\right]<0 .}
\end{gathered}
$$

Given an upward-sloping aggregate labor supply curve, the second-order derivative will surely be negative if the wage elasticity of labor supply weakly declines with the wage

$$
\frac{d \epsilon(w, L(w, \gamma), \gamma)}{d w}=\frac{\partial \epsilon}{\partial w}+\frac{\partial \epsilon}{\partial L} L_{w} \leq 0
$$

Once the wage has been determined by (9), the employment level can be found by calculating labor supply, implicitly defined by (4). 


\section{Positive Analysis}

In this section we investigate how wages and employment change with the intensity of social comparisons of the KUJ-type. First, we derive and illustrate the findings for the general utility function looked at thus far. Subsequently, we consider two often used specifications of preferences, in order to resolve some of the ambiguities which remain for the general formulation.

\subsection{A General Result}

The wage and employment effects of a change in the strength of social preferences are summarized in the following proposition.

Proposition 1. Suppose individual preferences are of the KUJ-type:

(a) Sufficient conditions for labor supply and employment to increase with the intensity of social comparisons are that (1) $\partial \epsilon / \partial \gamma \geq 0$ and $\partial \epsilon / \partial w \leq 0$, or (2) the wage does not fall.

(b) A sufficient condition for the wage to decrease with the intensity of social comparisons is that $\partial \epsilon / \partial \gamma \leq 0$ and $\partial \epsilon / \partial L \leq 0$.

Proof. The derivative of the labor supply curve $L(w, \gamma)$ with respect to $\gamma$, taking into account wage repercussions, is:

$$
\frac{d L(w, \gamma)}{d \gamma}=L_{\gamma}+L_{w} \frac{d w}{d \gamma}=L_{\gamma}-L_{w} \frac{\pi_{w \gamma}}{\pi_{w w}}
$$

If the wage rises, so does employment, c.f. (6), since the monopolist chooses a point on the labor supply curve. Substituting for the wage effect, we obtain:

$$
\frac{d L(w, \gamma)}{d \gamma}=L_{\gamma}-L_{w} \frac{f^{\prime \prime}(L) L_{\gamma}+\frac{w}{\epsilon^{2}}\left(\frac{\partial \epsilon}{\partial \gamma}+\frac{\partial \epsilon}{\partial L} L_{\gamma}\right)}{f^{\prime \prime}(L) L_{w}-\frac{1+\epsilon}{\epsilon}+\frac{w}{\epsilon^{2}}\left(\frac{\partial \epsilon}{\partial w}+\frac{\partial \epsilon}{\partial L} L_{w}\right)}=\frac{-L_{\gamma} \frac{1+\epsilon}{\epsilon}+\frac{w}{\epsilon^{2}}\left(L_{\gamma} \frac{\partial \epsilon}{\partial w}-L_{w} \frac{\partial \epsilon}{\partial \gamma}\right)}{\pi_{w w}}
$$

Since the denominator is negative according to (10), the employment effect is unambiguously positive for $\frac{\partial \epsilon}{\partial w} \leq 0$ and $\frac{\partial \epsilon}{\partial \gamma} \geq 0$. This proves part (a).

The derivative of the first-order condition of the firm (9) with respect to $\gamma$ is: 


$$
\pi_{w \gamma}=\frac{L(w, \gamma) \epsilon}{w}\left[f^{\prime \prime}(L) L_{\gamma}+\frac{w}{\epsilon^{2}}\left(\frac{\partial \epsilon}{\partial \gamma}+\frac{\partial \epsilon}{\partial L} L_{\gamma}\right)\right]
$$

Since labor supply rises with the intensity of social comparisons, see (7), the term in square brackets will surely be negative if the wage elasticity of labor supply rises neither with the strength of social comparisons nor with employment. This proves part (b).

We can explain the proposition graphically and thereby also provide intuition. Figure 1 contains the textbook illustration of a monopsony. The thin lines $(\gamma=0)$ refer to the case without social comparisons. As is well known, the marginal cost curve for the monopsonist is situated above the labor supply curve it faces. The relative difference between the marginal product of labor and the wage is determined by the inverse of the labor supply elasticity to the firm, i.e., Pigou's measure of exploitation (Boal and Ransom, 1997, p. 88).

Incorporating social comparisons $(\gamma \neq 0)$ has no impact on labor demand as it is independent of the employees' income. If workers exhibit jealousy, the intensity of which is measured by the parameter $\gamma$, the labor supply curve shifts downwards with $\gamma$ in the wage-employment space. The bold line illustrates this effect in Figure 1. Moreover, the slope of the labor supply curve is likely to change (cf. (6)). Accordingly, social comparisons also affect the monopsonist's marginal costs $w\left(1+\frac{1}{\epsilon}\right)$ via alterations in the labor supply elasticity. In Figure 1, we have depicted a situation where a larger prevalence of social comparisons increases employment and lowers wages. As our proposition clarifies, this is not the only feasible outcome. Suppose the intersection of the new marginal cost curve with the labor demand schedule lies to the right of the original intersection, as it is the case in Figure 1, and that the resulting wage weakly exceeds the level paid in the absence of social comparisons. The latter requirement, though, is not fulfilled in Figure 1. In this case, labor supply and employment surely rise, as indicated in part a2) of Proposition 1: First, the rightward shift in the labor supply curve increases employment, at a given wage. Second, a higher wage than before the shift implies a movement along the labor supply curve to the right. This is tantamount to a further rise in employment. Suppose, instead, that the wage falls. If the labor supply elasticity weakly rises with more intense social preferences and the lower wage, the marginal costs curve will surely move 
Figure 1: Wages and employment in monopsony with social comparisons

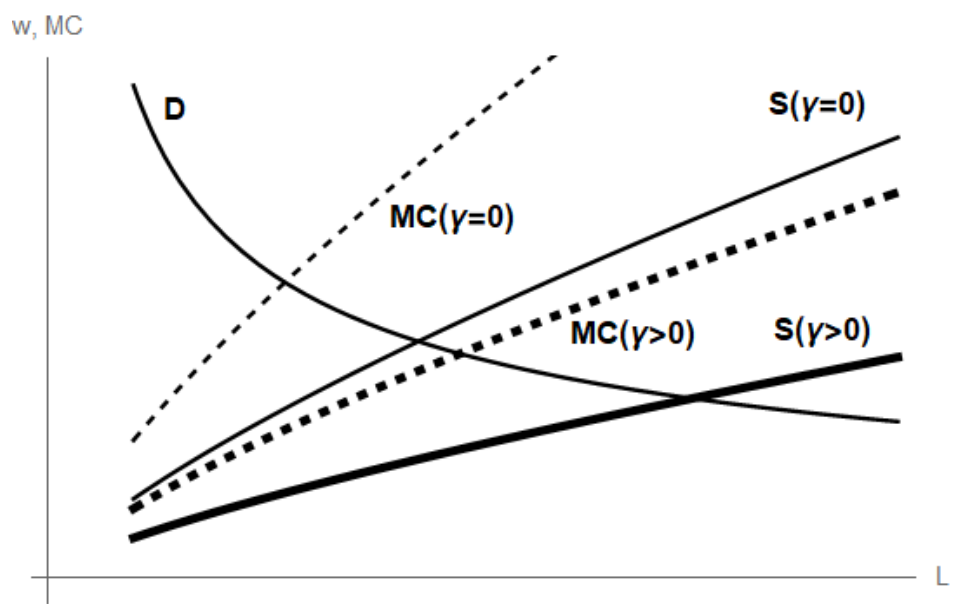

Notes: $S$ is labor supply and $D$ labor demand. Thin lines refer to the case of a monopsony without social comparisons $(\gamma=0)$, bold lines to a monopsony with social comparisons $(\gamma>0)$. Dashed lines are the marginal cost $(M C)$ curves to the monopsonist of hiring one more unit of labor.

downwards in the wage-employment space. This set of sufficiency requirements, as stated in part a1) of Proposition 1, also ensures that employment rises and is, again, compatible with the illustration in Figure 1.

Turning to wages, it is immediately obvious from inspection of Figure 1 that they will certainly fall if the marginal cost curve moves upwards. Such upward shift will come about if the labor supply elasticity declines with more intense social preferences. Since an upward shift, ceteris paribus, results in less employment, moreover, the labor supply elasticity must not increase with employment in order to ensure the negative wage effect. In Figure 1, these sufficiency requirements for a lower wage are not warranted. ${ }^{3}$

\subsection{Specific Utility Functions}

Proposition 1 formulates sufficiency conditions for a general specification of utility. Therefore, it is of interest to ascertain for which kind of preferences these conditions hold. Further-

\footnotetext{
${ }^{3}$ The proof of Proposition 1 relies on the derivatives of the labor supply curve and on variations in the labor supply elasticity. The specificities of the utility function and, in particular, the separability between consumption and working time, do not play a role. If, therefore, the separability simplification does not affect the characteristics of the aggregate labor supply curve, Proposition 1 will also apply for non-separable preferences.
} 
more, even if the requirements are not warranted it may nonetheless be possible to determine outcomes for less general specifications of preferences.

Due to reasons of tractability, the analysis of the effects of social preferences in various economic contexts mostly starts from the definition of a specific utility function (Grodner et al., 2011). Hence, there is no lack of candidates that we could consider. We will exemplify our general results with two utility functions, which have frequently been used. The first, additive or substractive formulation, assumes that absolute consumption differences matter and has been employed by Ljungqvist and Uhlig (2000), inter alia. It is given by:

$$
U\left(c, c^{r}, L\right)=\frac{1}{1-\beta}\left(\frac{c-\gamma c^{r}}{1-\gamma}\right)^{1-\beta}-A L
$$

where $A, \beta>0$ and $0<\gamma<1$. Our second example is a multiplicative specification, which focuses on relative consumption differences, suggested by Gali (1994):

$$
U(L)=\frac{1}{1-\beta}\left(\frac{c}{\left(c^{r}\right)^{\gamma}}\right)^{1-\beta}-A L,
$$

for which we assume $\beta>1$ in order to ensure KUJ preferences. In addition, $\gamma(1-\beta)+\beta>0$ guarantees that the labor supply curve to the monopsonist is upward-sloping and the existence of equilibrium (Dupor and Liu, 2003). Both formulations assume separability and also warrant the other assumption underlying our analysis, such as $U_{c}>0>U_{L}, U_{c^{r}}, U_{c c}$ and $U_{L L} \leq 0$. Our choice is also motivated by an ongoing discussion on whether social preferences should be modeled in relative or absolute terms (see, inter alia, Persson, 1995; Clark and Oswald, 1998; Choudhary and Levine, 2006; Pérez-Asenjo, 2011; Mujcic and Frijters, 2013). Thus, we consider an example for each case. Moreover, we continue to assume symmetry $\left(c=c^{r}\right)$ and specify a Cobb-Douglas production function, $f(L)=L^{m}, 0<m<1$.

Example 1 - Absolute consumption differences Since individuals regard reference consumption as given, the first-order condition for a maximum of utility as defined in (15) is:

$$
\frac{d U}{d L}=\left(\frac{c-\gamma c^{r}}{1-\gamma}\right)^{-\beta} \frac{1}{1-\gamma} w-A=0
$$


Given the assumptions stated above $\left(c=w L+\pi=L^{m}\right)$, aggregate labor supply is defined by:

$$
L^{-m \beta} \frac{1}{1-\gamma} w-A=0
$$

With $d L / d w=L /(m \beta w)>0$, the labor supply elasticity to the monopsonist becomes:

$$
\epsilon=\frac{d L}{d w} \frac{w}{L}=\frac{1}{m \beta}
$$

We can also verify that the aggregate labor supply curve shifts downwards in the wageemployment space with more intense social comparisons $\left(L_{\gamma}>0\right)$. As $\epsilon_{\gamma}=\epsilon_{L}=\epsilon_{w}=0$, it follows from Proposition 1 that employment increases in the prevalence of social comparisons, while wages decline. Therefore, social comparisons counteract the employment effects of a monopsony and aggravate the wage consequences.

Example 2 - Relative consumption differences Differentiation of (16) yields the firstorder condition of the worker's utility maximization problem as

$$
\frac{d U}{d L}=\frac{w}{c^{\beta}}-A\left(c^{r}\right)^{\gamma(1-\beta)}=0
$$

Aggregate labor supply to the monopsonist (for $c=c^{r}=L^{m}$ ) follows from

$$
z \equiv w-A L^{m(\gamma(1-\beta)+\beta)}=0
$$

Inserting $d L / d w>0$ into the labor supply elasticity to the firm gives

$$
\epsilon=\frac{d L / L}{d w / w}=\frac{1}{m(\gamma(1-\beta)+\beta)}
$$

Proposition 1 is based on the assumption that labor supply shifts outwards with $\gamma$. This will be the case if $z_{\gamma}>0$, that is $L>1$. As $\beta>1$ and $\gamma(1-\beta)+\beta>0$, it holds that $\partial \epsilon / \partial \gamma>0$ and employment unambiguously increases in the intensity of social comparisons. 
The wage is determined by the first-order condition

$$
b \equiv m L^{m-1}-w \frac{1+\epsilon}{\epsilon}=0 .
$$

Taking total differentials of $z$ and $b$ and applying Cramer's rule we get

$$
\frac{d w}{d \gamma}=\frac{-z_{\gamma} b_{L}+b_{\gamma} z_{L}}{z_{w} b_{L}-b_{w} z_{L}}
$$

It holds that $z_{w} b_{L}-b_{w} z_{L}<0$. The sign of the numerator is ambiguous. It, however, becomes negative if $m \rightarrow 1$, i.e. the production function becomes less concave and, consequently, the labor demand curve flatter in the wage-employment space (see the Appendix for a more detailed exposition). Therefore, a given change in marginal costs results in a greater expansion

of employment. In consequence, both the employment and the wage effect are positive. This shows that social comparisons counteract the negative employment effects of monopsonistic market power and that this may also be true with regard to wages.

\section{Normative Analysis}

In this section, we move beyond the confines of a positive analysis in which we have compared two market outcomes. For the normative investigation, we assume that a welfarist social planner maximizes utility of the representative individual. Thus, given our assumptions of homogeneous workers and the redirection of the monopsonist's profits to them, the social planner is solely interested in the efficiency properties of the allocation and her objective is given by $U=U(f(L), f(L), L)$. In Section 4.1, we derive the condition which ensures that the market equilibrium in the absence of any distortion constitutes the social planner's preferred outcome. Subsequently, in Sections 4.2 and 4.3 we demonstrate how restrictions either on wages or, alternatively, taxes, respectively subsidies, can be employed to generate the social planner's desired outcome as market equilibrium. 


\subsection{Optimality Versus Undistorted Market Outcome}

The setting we analyze is featuring two distortions: Market power by the employer and a consumption externality due to social comparisons. A welfarist social planner will aim for an employment level such that the gains and costs of expanding employment, taking into account both distortions, just balance out. Denoting the marginal utility from consumption in the absence (presence) of social comparisons by $U_{c}(\gamma=0)\left(U_{c}(\gamma \neq 0)\right)$, we have:

Proposition 2. A welfarist social planner confronted with two distortions, a monopsony and externalities due to social comparisons, will only set an employment level that equals the one that results in a competitive market in the absence of social comparisons if $\frac{U_{c}(\gamma=0)-U_{c}(\gamma \neq 0)}{U_{c^{r}}}=1$.

Proof. Maximizing $W=U(f(L), f(L), L)$ with respect to $L$, yields as first-order condition in the presence of social comparisons $(\gamma \neq 0)$ :

$$
\frac{d W}{d L}_{\gamma \neq 0}=\left(U_{c}(\gamma \neq 0)+U_{c^{r}}\right) f^{\prime}(L)+U_{L}(L)=0 .
$$

Denote the resulting employment level by $L^{o p t, \gamma \neq 0}$. The second-order condition holds, given the assumptions with regard to utility and the production function, $f^{\prime \prime}(L), U_{c c}, U_{c^{r} c^{r}}<0$, $U_{L L} \leq 0$.

Because there are no distributional effects of the market outcome on welfare in the present setting, the employment level resulting in a competitive market without distortions is equivalent to the social planner's choice, assuming $\gamma=0$. Hence, we can determine the market outcome for $\gamma=0$ by maximizing welfare $W$. The resulting employment level, $L^{o p t, \gamma=0}$, is determined by:

$$
\frac{d W}{d L}_{\gamma=0}=U_{c}(\gamma=0) f^{\prime}(L)+U_{L}(L)=0 .
$$

Since $U_{L}(L)$ and $f^{\prime}(L)$ solely depend on employment, the social planner's choice in the presence of social comparisons and the outcome in a competitive market in their absence will coincide $\left(L^{o p t, \gamma \neq 0}=L^{o p t, \gamma=0}\right)$, if $U_{c}(\gamma \neq 0)+U_{c^{r}}=U_{c}(\gamma=0)$. If $U_{c}(\gamma \neq 0)+U_{c^{r}}>U_{c}(\gamma=0)$ holds, $L^{o p t, \gamma \neq 0}$ will exceed $L^{o p t, \gamma=0}$, as $W$ is strictly concave in $L$. 
The intuition (for $\gamma>0$ ) is as follows: The social marginal utility from consumption in the presence of social comparisons differs from the respective (individual and social) marginal utility in the absence of such effects for three reasons: First, employees are working more hours, raising consumption. This, ceteris paribus, decreases the marginal utility from consumption, given the strict concavity of $U$. Second, the marginal utility from own consumption is affected by the reference level of consumption and will be higher in the presence of social comparisons, as $U_{c c^{r}}>0$. Third, the welfarist social planner takes into account that an expansion of labor supply not only alters consumption of the individual under consideration, but also the reference level. This, ceteris paribus, lowers the gain from working and consuming more. If the sum of all effects is positive and, therefore, the gain from additional consumption is greater in the presence of social comparisons than in an undistorted market without such comparison effects, optimal labor supply and employment will be higher. ${ }^{4}$

Considering our particular utility functions, we may note that for the difference specification of utility $(15)$ we have $U_{c}(\gamma \neq 0)=\left(c^{-\beta}\right) /(1-\gamma)$ and $U_{c^{r}}=-\gamma\left(c^{-\beta}\right) /(1-\gamma)$ for $c=c^{r}=f(L)$. These derivatives imply that $U_{c}(\gamma=0)-U_{c}(\gamma \neq 0)=U_{c^{r}}$ holds. For the formulation of preferences (16) proposed by Gali (1994), we have $U_{c}(\gamma \neq 0)=c^{-\beta+\gamma(\beta-1)}$ and $U_{c^{r}}=-\gamma c^{-\beta+\gamma(\beta-1)}$. Accordingly, the ratio defined in Proposition 2 is given by:

$$
\frac{U_{c}(\gamma=0)-U_{c}(\gamma \neq 0)}{U_{c^{r}}}=\frac{c^{\gamma(\beta-1)}-1}{\gamma c^{\gamma(\beta-1)}}
$$

This ratio will only be unity for particular values of output and consumption, but will not generally attain this value.

The two starting points of our investigations are the predictions that, first, employment in monopsony declines below the competitive level resulting in the absence of social comparisons, while, second, KUJ preferences induce excessive employment in a competitive setting. Proposition 2 clarifies that even if the two effects just balance out and the outcome results

\footnotetext{
${ }^{4}$ The above line of reasoning relies on the feature that marginal disutility from working, $U_{L}$, is independent of social preferences. This will clearly be the case if utility is separable in consumption and working time $\left(U_{c L}=\right.$ $U_{c^{r} L}=0$ ). If this assumption is relaxed, the ratio defined in Proposition 2 would have to be complemented by the ratio of marginal disutility from work, $U_{L}$, in the presence and absence of social preferences. Given this modification, the findings stated above would be unaffected by a more general specification of preferences.
} 
which would prevail in a competitive setting without social comparisons, this employment level will only be first-best for particular utility functions. The reason is that a welfarist social planner, on the one hand, incorporates that individual preferences feature social comparisons. On the other hand, she takes the externality of such preferences into account. The two effects balance out for certain specifications of utility, namely those for which the marginal utility from own and reference consumption is proportional to own consumption. A straightforward policy implication is that an employment level of a competitive, undistorted market cannot, in general, guide policymaking.

\subsection{Wage Regulation}

In the previous section, we explored which level of employment would be chosen if the social planner could determine employment. Typically, analyses of monopsonies have considered settings in which a social planner or government does not have the ability to determine employment directly, but can establish the price of labor, while the firm continues to choose the number of employees (Boal and Ransom, 1997; Manning, 2003). In accordance with this approach, we now assume that the social planner can only fix the wage. This may be a minimum wage or a wage cap. Our main insight is given by:

Proposition 3. Let the ratio $-\frac{U_{c^{r}}}{U_{c}(\gamma \neq 0)}$ be denoted by $\gamma$. A welfarist social planner who can affect welfare by fixing the wage, will set it at higher level than the monopsonist if

$$
1-\gamma>\frac{\epsilon}{1+\epsilon}
$$

Proof. Employment resulting in monopsony, denoted by $L^{M o n}$, is implicitly defined by (9). Moreover, labor supply is given by (2). Combining both equations, yields:

$$
f^{\prime}\left(L^{M o n}\right) \frac{\epsilon}{1+\epsilon}=-\frac{U_{L}\left(L^{M o n}\right)}{U_{c}(\gamma \neq 0)}
$$

Evaluating the social planner's choice as defined in (25) at $L=L^{M o n}$ yields: 


$$
\begin{gathered}
\frac{d W}{d L}_{\gamma \neq 0, L=L^{M o n}}=\left(U_{c}(\gamma \neq 0)+U_{c^{r}}\right) f^{\prime}\left(L^{M o n}\right)+U_{L}\left(L^{M o n}\right) \\
=-\frac{U_{L}\left(L^{M o n}\right)}{U_{c}(\gamma \neq 0)}\left[U_{c}(\gamma \neq 0)+U_{c^{r}}\right] \frac{1+\epsilon}{\epsilon}+U_{L}\left(L^{M o n}\right) \\
=U_{L}\left(L^{M o n}\right)\left[-\frac{1+\epsilon}{\epsilon}\left(1+\frac{U_{c^{r}}}{U_{c}(\gamma \neq 0)}\right)+1\right] .
\end{gathered}
$$

Using $\frac{U_{c^{r}}}{U_{c}(\gamma \neq 0)}=-\gamma$, the social planner's objective will, hence, be maximized by the market outcome if $1-\gamma=\epsilon /(1+\epsilon)$ and she will want to increase (reduce) employment above (below) $L^{M o n}$ if $(1-\gamma)(1+\epsilon) / \epsilon>(<) 1$ holds, given $U_{L}<0$. Employment can be increased by (marginally) raising the wage above the level set by the monopsonist. Therefore, if $(1-\gamma)(1+$ $\epsilon) / \epsilon>1$ holds, the social planner will raise the wage. If, however, the reverse inequality applies, the social planner will restrict labor supply by imposing a maximum wage.

The intuition is as follows: Employment in monopsony in the absence of other distortions is too low because marginal costs exceed the wage by the factor $(1+\epsilon) / \epsilon$. The labor supply effect of not taking into account social comparisons if preferences exhibit jealousy $(\gamma>0)$ is due to the increase in the marginal rate of substitution from $-U_{L} / U_{c}(\gamma=0)$ to $-U_{L} /\left(U_{c}(\gamma \neq\right.$ $\left.0)+U_{c^{r}}\right)$. Assume $\frac{U_{c^{r}}}{U_{c}(\gamma \neq 0)}=-\gamma$, which is fulfilled for specifications (15) and (16), and also for more general descriptions of preferences $U=U\left(c-\gamma c^{r}, L\right)$ and $U=U\left(c /\left(c^{r}\right)^{\gamma}, L\right) .^{5}$ In consequence, the marginal rate of substitution equals $-U_{L} /\left(U_{c}(\gamma \neq 0)(1-\gamma)\right)$. The two distortions will exactly neutralize each other if the labor demand impact of higher costs, $(1+\epsilon) / \epsilon$, equals the labor supply effect of ignoring social comparisons, measured by $1 /(1-\gamma)$. If the cost impact is higher, i.e. if $(1+\epsilon) / \epsilon>1 /(1-\gamma)$, the social planner will want to expand employment. In a monopsony this is feasible by raising the wage because a (small) general wage increase will actually lower the marginal cost of employment.

In a "standard" monopsony, a minimum wage slightly above the level set by the monopsonist

\footnotetext{
${ }^{5}$ Note that the parameter $\gamma, \gamma \equiv-\frac{U_{c^{r}}}{U_{c}(\gamma \neq 0)}$, measuring the strength of social comparisons, is equivalent to the (negative of the) degree of positionality as used by Aronsson and Johansson-Stenman in a series of papers (see, e.g., Aronsson and Johansson-Stenman, 2008, 2010), given their specification of utility as, $U=U\left(c, L, c-c^{r}\right)$.
} 
will always be beneficial. Our result shows that this will not generally be the case if workers exhibit social preferences. More precisely, a wage increase will only enhance employment and raise welfare if the extent of monopsony power outweighs the strength of social comparisons. ${ }^{6}$ Therefore, Proposition 3 establishes an easily observable and widely applicable condition which helps to ascertain whether a minimum wage or a wage cap is welfare-enhancing.

Empirically, there is evidence that the parameter $\gamma$ is somewhat less than 0.5. Wendner and Goulder (2008) summarize results from survey-based studies and conclude that $\gamma$ is likely to be greater than 0.2 but less than 0.4 . This is consistent with findings based on panel data by Alvarez-Cuadrado et al. (2016), and experimental evidence in Alpizar et al. (2005). Estimates of the wage elasticity of labor supply vary widely across labor markets and countries (Manning, 2011; Sokolova and Sorensen, 2018). Estimates as low as 0.1 (cf. Dube et al., 2020) seem to be an exception, while values of $\epsilon$ of unity or more in monoposonistic settings appear to be more common. Assuming, therefore, $\gamma=0.33$ and $\epsilon=1$ suggests that the monopoly distortion dominates, such that a minimum wage enhances welfare. However, if the intensity of social comparisons is somewhat higher and exceeds $\gamma=0.5$ or, alternatively, the labor supply elasticity is greater than $\epsilon=2$, the implications are reversed and a wage cap will benefit society. This ambiguity clarifies that the combined analysis of social comparisons and monopsony not only satisfies academic curiosity, but is also of utmost policy relevance.

\subsection{Taxes and Subsidies}

While a restriction on the level of wages is one feasible instrument to affect employment and to increase welfare, there is ample evidence that minimum wages are not always paid. Moreover, both the monopsonist and individual employees have incentives not to adhere to wage regulations. $^{7}$ Hence, a social planner may want to employ other means to enhance the society's payoff, such as taxes or subsidies. Taxes which internalize the externalities due to social comparisons have been analyzed comprehensively, generally assuming competitive

\footnotetext{
${ }^{6}$ This condition is independent of the separability feature imposed on preferences above $\left(U_{c L}=U_{c^{r} L}=0\right)$ because the derivation of the proposition does not require second-order or cross derivatives.

${ }^{7}$ See the evidence surveyed in Danziger (2010) who then builds a model to show that imperfectly enforced minimum wages in a competitive labor market will induce small firms to become monopsonists.
} 
labor markets (see, inter alia, Duesenberry, 1949; Boskin and Sheshinski, 1978; Persson, 1995; Ireland, 1998; Corneo, 2002; Gómez, 2008; Micheletto, 2011; Dodds, 2012; Aronsson and Johansson-Stenman 2010; 2013; 2018; Eckerstorfer and Wendner, 2013, Eckerstorfer, 2014, and Wendner, 2014). Moreover, some contributions investigate the efficiency impact of subsidies or taxes in monopsonistic labor markets. Manning (2004) ascertains the effects of a progressive income tax system in a general equilibrium search and matching framework. Cahuc and Laroque (2014) analyze taxation in a monopsonistic labor market that hosts heterogeneous workers, and Strobl and Walsh (2007) allow firms to choose wages and hours of work when examining the effects of subsidies. However, the impact of both distortions - monopsony and externalities resulting from social comparisons - on optimal tax policy has not been considered.

In order to tackle this issue, we assume that the firm pays a payroll tax, $t, t>0$, or receives an according subsidy, $t<0$. Profits can, hence, be expressed as:

$$
\pi=f(L(w, \gamma))-(1+t) w L(w, \gamma)
$$

Since considerations of individuals are unaffected, the features of the labor supply curve are the same as outlined in Section 2.2. Any tax receipts are returned in a lump-sum manner. Similarly, in case of $t$ being a subsidy, a profit tax or another non-distortionary means of raising revenue is assumed to balance the government's budget. Consequently, the only impact of the tax is the change in the firm's wage choice.

Maximization of profits as defined in (31), possibly amended to incorporate profit taxation or lump-sum payments, yields as first-order condition

$$
f^{\prime}\left(L^{M o n, t}\right)-w(1+t) \frac{1+\epsilon}{\epsilon}=0
$$

where $L^{\text {Mon,t }}$ denotes the employment level (implicitly) chosen by the monopsonist in the presence of a payroll tax or subsidy. Combining (32) with the outcome of the individual optimization (cf. (2)), we obtain: 


$$
f^{\prime}\left(L^{M o n, t}\right)=-(1+t) \frac{1+\epsilon}{\epsilon} \frac{U_{L}\left(L^{M o n, t}\right)}{U_{c}(\gamma \neq 0)} .
$$

The socially optimal outcome is defined by (25). Evaluating this derivative at the market outcome, $L^{M o n, t}$, and using our notation of $\frac{U_{c^{r}}}{U_{c}(\gamma \neq 0)}=-\gamma$, we obtain:

$$
\begin{aligned}
\frac{d W}{d L}_{\gamma \neq 0, L=L^{M o n, t}}= & -\left(U_{c}(\gamma \neq 0)+U_{c^{r}}\right)(1+t) \frac{1+\epsilon}{\epsilon} \frac{U_{L}\left(L^{M o n, t}\right)}{U_{c}(\gamma \neq 0)}+U_{L}\left(L^{M o n, t}\right) \\
& =U_{L}\left(L^{M o n, t}\right)\left[1-(1-\gamma)(1+t) \frac{1+\epsilon}{\epsilon}\right] .
\end{aligned}
$$

The expression in square brackets will be zero, such that welfare is maximized if

$$
t^{o p t}=\frac{1}{1-\gamma}\left[\frac{\epsilon}{1+\epsilon}-(1-\gamma)\right]
$$

The optimal tax or subsidy rate will be zero if the two distortions just balance out and the wage set by the monopsonist induces the optimal employment level. If $1-\gamma<\epsilon /(1+\epsilon)$, the impact of social comparisons dominates the consequences of market power and $t^{\text {opt }}$ will be positive. In a world in which the labor market is competitive $(\epsilon \rightarrow \infty)$, the optimal tax equals $t^{\text {opt }}(\epsilon \rightarrow \infty)=\gamma /(1-\gamma)=-U_{c^{r}} /\left(U_{c}(\gamma \neq 0)+U_{c^{r}}\right)>0$. If the effects of social comparisons are relatively weak, and $1-\gamma<\epsilon /(1+\epsilon)$, the monopsonist will be subsidized. In the limiting case of preferences exhibiting no social comparisons, $t^{o p t}(\gamma=0)=-1 /(1+\epsilon)<0$.

Alternatively, an income tax, $\tau$, or consumption tax, $s$, could be imposed on workers, such that their budget constraint, in the absence of any transfer or lump-sum tax, reads $w L(1-\tau)+\pi-c=0$ or $w L+\pi-c(1+s)=0$. In this case, the labor supply elasticity also depends on the $\operatorname{tax}(\tau, s>0)$ or subsidy $(\tau, s<0)$. Proceeding in the same manner as in the derivation of $t^{\text {opt }}$, the optimal income tax or subsidy rate, setting the consumption tax rate to zero, is (implicitly) defined by:

$$
\tau^{o p t}=\frac{1+\epsilon\left(\tau^{o p t}\right)}{\epsilon\left(\tau^{o p t}\right)}\left[\frac{\epsilon\left(\tau^{o p t}\right)}{1+\epsilon\left(\tau^{o p t}\right)}-(1-\gamma)\right]
$$


while $s^{o p t}=t^{\text {opt }}$. The optimal income tax rate, $\tau^{\text {opt }}$, will be positive (negative) if $1-\gamma<$ $(>) \epsilon /(1+\epsilon)$. In the absence of labor market imperfections, the optimal tax rate equals $\tau^{o p t}(\epsilon \rightarrow \infty)=\gamma=-U_{c^{r}} / U_{c}(\gamma \neq 0)>0 .^{8}$

We can summarize the considerations of this subsection in:

Proposition 4. Let the ratio $-\frac{U_{c^{r}}}{U_{c}(\gamma \neq 0)}$ be denoted by $\gamma$ and assume that a social planner can only affect welfare by setting tax or subsidy rates. A welfarist social planner will set the tax/subsidy rate on labor costs or on consumption expenditure in accordance with (35) and the tax/subsidy rate on wage income in line with (36).

Proof. Follows from the above.

Accordingly, in our simple setting either a minimum wage or a subsidy can raise employment if it is below the optimal level. Alternatively, a tax or a wage cap are both equally suitable as policy instruments if social comparisons of the KUJ-type dominate the monopsony distortion and employment needs to be reduced, in order to enhance welfare.

\section{Admiration}

Our analysis has thus far focused on jealous individuals. Such type of preferences induce workers to supply labor excessively. Hence, jealousy may counteract the decline in employment due to monopsony power. Since admiration reduces employment in a competitive labor market, this type of consumption externality is aggravated by monopsony power. Nonetheless, it is worthwhile to also consider the case of admiration. Such preferences imply that utility is an increasing function of reference consumption, $U_{c^{r}}>0$ (Dupor and Liu, 2003). In our setting, this is equivalent to individuals exhibiting Running-away-from-the-Joneses (RAJ) preferences. Formally, admiration implies that $\gamma<0$ holds in our specifications of utility such that $U_{c c^{r}}, U_{c \gamma}<0$. From (7), $L_{\gamma}<0$ results. Analogously to Proposition 1 we can now

\footnotetext{
${ }^{8}$ See, e.g., Persson (1995), Ljungqvist and Uhlig (2000), Dupor and Liu (2003), Aronsson and JohanssonStenman $(2010 ; 2013 ; 2018)$. From the results obtained by Liu and Turnovsky (2005) and Alvarez-Cuadrado (2007) we can derive comparable expressions if taking into account that they incorporate more than one tax rate.
} 
state that more intense social comparisons will raise the wage if the labor supply elasticity, $\epsilon$, does not decline with $\gamma,(\partial \epsilon / \partial \gamma \geq 0)$, and does not increase with employment $(\partial \epsilon / \partial L \leq 0)$. These requirements ensure that the monopsonist's marginal cost curve will shift downwards in the wage-employment space. Furthermore, more pronounced social comparisons will reduce employment in the presence of admiration if either the wage does not rise or $\partial \epsilon / \partial w \leq 0$ and $\partial \epsilon / \partial \gamma \leq 0$ hold

Inspection of Proposition 2 reveals that its content is independent of the sign of $\gamma$ and, thus, of the nature of social comparisons. Therefore, it applies to the case of admiration, as well. This is because the proposition formulates a condition in which the undistorted market equilibrium in the absence of social comparisons constitutes the benchmark for a welfarist economic policy. The important aspect is whether preferences are (specified) such that the effect of undertaking social comparisons is equivalent to the impact of internalizing the consumption externality. In this case, the competitive outcome in a world without distortions constitutes the first-best. It is, however, irrelevant for the characterization of the benchmark if individuals consume too much or too little, i.e. if the consumption externality is due to jealousy or admiration.

In contrast and as indicated above, Propositions 3 and 4 yield clear-cut predictions in the case of admiration. If $\gamma<0$ holds, $(1-\gamma)(1+\epsilon) / \epsilon>1$ results, and both monopsony power and social comparisons lower employment to below the first-best. Thus, admiration strengthens the case for a minimum wage and subsidies, the rates of which increase with the strength of social comparisons.

\section{Paternalistic Social Planner}

The analysis in Sections 4 and 5 has been based on the assumption that the social planner maximizes the utility of the representative worker. However, it has been argued that individual preferences which incorporate jealousy may be inappropriate as basis for a normative investigation. Accordingly, the analysis of optimal taxation has occasionally been based on the assumption that the social planner is paternalistic or non-welfarist and maximizes the payoff

of the representative consumer, ignoring repercussions of her choice via changes in utility due 
to social comparisons (see, for example, Aronsson and Johansson-Stenman, 2018; Dodds, 2012; Eckerstorfer and Wendner, 2013; and Micheletto, 2011). ${ }^{9}$ While it is clearly debatable if jealousy harms another individual, if this individual has no such preferences and, thus, if jealousy has to be disregarded, it is nonetheless insightful to investigate in how far Propositions 3 and 4 depend on the specification of the normative objective.

Therefore, we subsequently assume that the social planner is paternalistic (or non-welfarist). We denote her objective by $W^{p}$ and indicate the modification by expressing utility and marginal utility as functions of an exogenous level of reference consumption $\bar{c}^{r}:{ }^{10}$

$$
W^{p}=U\left(c, \bar{c}^{r}, L\right)
$$

As in Section 4, we make use of the assumptions that workers are homogeneous and that they obtain the monopsonist's profits as (exogenous) income. Consequently, we continue to focus on the efficiency properties of the allocation. Maximization of $W^{p}$ yields:

$$
\frac{d W^{p}}{d L}=U_{c}\left(f(L), \bar{c}^{r}\right) f^{\prime}(L)+U_{L}(L)=0
$$

Denoting the ratio of marginal utility from own consumption when repercussions via social preferences are ignored and the marginal utility in their presence by $\mu(L, \gamma)=\frac{U_{c}\left(f(L), \bar{c}^{r}\right)}{U_{c}(f(L), f(L), \gamma)}$, we can establish:

Proposition 5. A paternalistic social planner who can affect welfare solely by

a) fixing the wage, will set it at higher level than the monopsonist if $\mu(L, \gamma)>\frac{\epsilon}{1+\epsilon}$, or

b) taxing or subsidizing labor costs ( $t$ ) or consumption expenditure (s), will set the tax/subsidy rate equal to $t^{o p t, W}=s^{o p t, W}=\frac{1}{\mu(L, \gamma)}\left[\frac{\epsilon\left(s^{o p t, W}\right)}{1+\epsilon\left(s^{o p t, W}\right)}-\mu(L, \gamma)\right]$, or

c) taxing or subsidizing wage income $(\tau)$, will set the tax/subsidy rate equal to $\tau^{\text {opt }, W}=$ $1-\mu(L, \gamma) \frac{1+\epsilon\left(\tau^{o p t, W}\right)}{\epsilon\left(\tau^{o p t, W}\right)}$.

\footnotetext{
${ }^{9}$ Aronsson and Johansson-Stenman (2018) provide a thorough discussion of the merits of such an approach.

${ }^{10}$ Hence, we adopt the approach chosen, for example, by Aronsson and Johansson-Stenman (2018) and Aronsson et al. (2019). If we, instead, assume that $W^{p}$ depends on consumption, $c$, and working time, $L$, only (see Dodds, 2012, inter alia), our subsequent results would be qualitatively the same, because variations in the arguments of the objective have the same impact, irrespective of whether reference consumption is held constant or omitted.
} 
Proof. Evaluating the first-order condition (38) at the market outcome, as defined by (29), and taking into account that marginal utility from work only depends on $L$, yields:

$$
\begin{gathered}
{\frac{d W^{p}}{d L}}_{\gamma \neq 0, L=L^{M o n}}=-U_{c}\left(f\left(L^{M o n}\right), \bar{c}\right) \frac{U_{L}\left(L^{M o n}\right)}{U_{c}\left(f\left(L^{M o n}\right), f\left(L^{M o n}\right), \gamma\right)} \frac{1+\epsilon}{\epsilon}+U_{L}\left(L^{M o n}\right) \\
=U_{L}\left(L^{M o n}\right)\left[1-\mu\left(L^{M o n}, \gamma\right) \frac{1+\epsilon}{\epsilon}\right] .
\end{gathered}
$$

The social planner's objective will, hence, be maximized by the market outcome if $\mu(L, \gamma)=$ $\epsilon /(1+\epsilon)$ and she will increase (reduce) employment above (below) $L^{M o n}$ if $\mu(L, \gamma)(1+\epsilon) / \epsilon>$ $(<) 1$ holds, given $U_{L}<0$. Since employment can be increased by (marginally) raising the wage above the level chosen by the monopsonist, this proves part a) of the Proposition.

If the firm pays a tax on labor costs, $t$, the market outcome can be described by (33). Substituting in (38), we obtain:

$$
\begin{gathered}
\frac{d W^{p}}{d L} \gamma \neq 0, L=L^{M o n, t}=-U_{c}\left(f\left(L^{M o n, t}\right), \overline{c^{r}}\right) \frac{U_{L}\left(L^{M o n, t}\right)}{U_{c}\left(f\left(L^{M o n, t}\right), f\left(L^{M o n, t}\right), \gamma\right)}(1+t) \frac{1+\epsilon}{\epsilon}+U_{L}\left(L^{M o n, t}\right) \\
=U_{L}\left(L^{M o n, t}\right)\left[1-\mu\left(L^{M o n, t}, \gamma\right)(1+t) \frac{1+\epsilon}{\epsilon}\right]
\end{gathered}
$$

Solving this expression yields $t^{o p t, W}$ as defined in Proposition 5.

If the tax is levied on consumption expenditure, such that the worker's budget constraint equals $w L+\pi-c(1+s)=0$, the market equilibrium can be characterized by:

$$
f^{\prime}\left(L^{M o n, s}\right)=-(1+s) \frac{1+\epsilon}{\epsilon} \frac{U_{L}\left(L^{M o n, s}\right)}{U_{c}\left(f\left(L^{M o n, s}\right), f\left(L^{M o n, s}\right), \gamma\right)} .
$$

Substituting in the first-order condition (38), and evaluating it at the market outcome, yields $s^{o p t, W}=t^{o p t, W}$, where $\epsilon=\epsilon\left(s^{o p t, W}\right)$. This proves part b) of the Proposition.

Finally, if the tax is levied on labor income, $\tau$, the market outcome is given by: 


$$
f^{\prime}\left(L^{M o n, \tau}\right)=-\frac{1+\epsilon}{\epsilon(1-\tau)} \frac{U_{L}\left(L^{M o n, \tau}\right)}{U_{c}\left(f\left(L^{M o n, \tau}\right), f\left(L^{M o n, \tau}\right), \gamma\right)}
$$

Proceeding in the same manner as above, part c) can be established.

The ratio of marginal utilities, $\mu(L, \gamma)$, is positive and less than unity if individuals exhibit KUJ-preferences, and greater than one for RAJ-preferences. From the perspective of the paternalist government, the ratio measures the distortion due to social preferences. While the gain from more work for the social planner is given by the increase in consumption for the representative worker, due to the rise in output, the gain for the worker is larger in the case of KUJ-preferences. This is the case because the worker also enhances his or her social status. Since the utility loss from working more is unaffected by social preferences, the individual incentives to work more are greater than the socially optimal ones. In consequence, labor supply in the presence of KUJ-preferences is, ceteris paribus, excessive not only for a welfarist but also for a paternalistic social planner. However, as the labor market features a monopsonistic employer, employment is, ceteris paribus, too low. Proposition 5, part a) indicates that if the supply side distortion, as captured by $1 / \mu(L, \gamma)$, exceeds the demand side distortion, $(1+\epsilon) / \epsilon$, wages need to be lowered because employment is excessive. In line with this, labor costs, consumption, or income will be taxed if $\mu(L, \gamma)<\epsilon /(1+\epsilon) .{ }^{11}$

Turning to our particular utility functions (15) and (16), the marginal utility from own consumption, holding constant the reference level or, alternatively, setting $\gamma=0$, we obtain $U_{c}\left(f(L), \bar{c}^{r}\right)=c^{-\beta}$ for $c=f(L)$. If the repercussions of a marginal variation in consumption via reference consumption are taken into account, marginal utility for the specification (15) of preferences is given by $U_{c}(f(L), f(L), \gamma)=\left(c^{-\beta}\right) /(1-\gamma)$. In consequence, we obtain $\mu(L, \gamma)=$ $U_{c}\left(f(L), \bar{c}^{r}\right) / U_{c}(f(L), f(L), \gamma)=1-\gamma$. Comparing Proposition 5 with Propositions 3 and 4 , we can observe that for this specification of preferences, the normative implications of the joint existence of monopsony power and social preferences are independent of social planner's preferences. This is the case because $U_{c}(f(L), f(L), \gamma)-U_{c^{r}}(f(L), f(L), \gamma)=U_{c}(f(L))$ holds

\footnotetext{
${ }^{11}$ Note that if utility were not separable, $U_{c L}, U_{c^{r} L} \neq 0$, the ratio $\mu(L, \gamma)$ would have to be redefined to also include the ratio of the marginal utility from work in the presence of social preferences and when they are ignored. Given this modification, subsequent results would be unaffected.
} 
for the utility function as defined in (15). This is also the reason why the undistorted market outcomes coincides with a welfarist social planner's objective. While a welfarist social planner aims to internalize the consumption externality, a paternalist wants workers to behave as if social preferences did not exist. Although the objectives of a welfarist and a paternalist social planner therefore differ, their choice of wages or taxes/subsidies will be the same. This assertion holds not only for the preferences defined in (15), but more generally for all difference specifications of utility, $U=U\left(c-\gamma c^{r}, L\right) .{ }^{12}$

For the formulation of preferences (16) proposed by Gali (1994), we have $\left.U_{c}(f(L), f(L), \gamma)\right)=$ $c^{-\beta+\gamma(\beta-1)}$, implying that $\mu(L, \gamma)=c^{\gamma(\beta-1)}=f(L)^{\gamma(\beta-1)}$. Therefore, the social planner's choice of wages or taxes depends not only on the strength of social preferences. This is because the extent of the distortion resulting from social preferences, which the paternalist social planner needs to internalize, varies with the consumption level. Consequently, for the multiplicative specification of preferences (16) the behaviour of a paternalist social planner will deviate from that of its welfarist counterpart.

In the case of admiration and RAJ-preferences, individuals will, from a paternalistic social planner's view point, perceive their own marginal utility to be insufficient. Proposition 5 indicates that such social preferences and also a monopsony require higher employment. This can be achieved by either setting a minimum wage or by subsidizing labor cost, income, or consumption. Hence, policy conclusions are qualitatively unaffected by the specification of the normative benchmark.

Summarizing our findings, we can conclude that the social planner's basic trade-off is independent of her objective. The optimal response in terms of wages or taxes/ subsidies depends on the strength of the monoposony distortion relative to the preference distortion. Although at first sight, the nature of the latter externality is fundamentally different for a welfarist and a paternalistic social planner, the implications for wage regulation and tax policy are the same for additive preferences. This is the case because the extent of the consumption externality, which is relevant for the welfarist objective, is the same as the extent of the deviation from

\footnotetext{
${ }^{12}$ A similar result is obtained by Aronsson and Johansson-Stenman (2018) who look at optimal taxation and show (cf. Proposition 1 and Corollary 1) that the marginal tax rate chosen by a welfarist and a paternalist social planner are the same if individuals are homogeneous and preferences are additive.
} 
the undistorted outcome, which determines a paternalist's behavior. If preferences are determined by the ratio of own and reference consumption, a welfarist and a paternalistic social planner's actions will differ quantitatively, as the relevant extent of the preference distortion also depends on the consumption level for the latter, but not the former objective.

\section{Conclusions}

There is ample evidence for the existence of non-competitive labor markets on the one hand, and social comparisons on the other hand. Thus far, the consequences of the simultaneous occurrence of the two distortions on wages, employment, and potential government interventions have hardly been explored.

In our analysis, we derive conditions which allow us to sign the wage and employment effects of social comparisons in monopsony. As the marginal wage costs of a monopsonist depend on the labor supply elasticity it faces, the effects can be determined if we know the direct impact of social comparisons on the labor supply elasticity, and the indirect consequences via changes in equilibrium wage and employment levels. We derive fairly general conditions on the labor supply elasticity to the firm that allow us to sign the total impact, i.e. the sum of the direct and indirect effects, of more intense social comparisons on wages and employment. Moreover, we provide examples for these more general conditions by deriving the relevant variations for two specific utility functions. As we let workers compare their consumption in absolute terms using a utility function suggested by Ljungqvist and Uhlig (2000), we find that employment increases in the prevalence of social comparisons, while wages decline. Using a utility function as in Gali (1994) we derive for a case of relative comparisons that the employment and the wage effect of more intensive social comparisons will both be positive if the production function is not too concave. Thus, in contrast to social comparisons in oligopsony (Goerke and Neugart, 2017), the wage effect of social comparisons is ambiguous in monopsony. In the major part of the paper, we address the welfare effects that the two potentially countervailing distortions have. Again, while a stronger prevalence of social comparisons increases welfare in oligopsony, we get equivocal effects in monopsony. Interestingly, a welfarist social planner will 
not necessarily suggest an employment level equal to the one in a competitive market without social comparisons. She will only do so for rather special properties on the marginal utility of a worker's own and reference consumption being fulfilled. This is in contrast to the choice of a paternalistic social planner who by definition will aim for the undistorted market outcome.

Our findings bear novel and important policy implications. A social planner who tries to achieve the optimal employment level by setting wages would not always employ a minimum wage. If the labor supply elasticity to the firm is sufficiently large, she would rather cap wages. Such a wage restriction will prevent the monopsonist from choosing employment in excess of the optimal level. This will be the case if the distortion due to social comparisons is strong enough. Analogously, we find conditions for an optimal use of either subsidies, or alternatively, taxes in a monopsony with social comparisons. Given the evidence that the labor supply elasticity to a monopsonist varies with the business cycle (Hirsch et al., 2018), this implies that optimal policy may alternate between minimum and maximum wages, or positive and negative tax rates, respectively. A qualitatively similar conclusion emerges if supply elasticities vary across labor markets, providing an additional argument for regional differentiations of wage regulations. Such challenges to determining optimal policies would be augmented if also the intensity of social comparisons varied with the economic situation. Importantly, these conclusions are independent of the exact specification of the welfare objective.

In our set-up, focusing on the efficiency properties of the interaction of market power and consumption externalities, one instrument is sufficient to achieve the social planner's objective. Therefore, in Section 4, we consider wages and taxes separately. If the social planner pursued a distributional objective in addition, for example, because individuals were heterogeneous ex-post or firms were not owned by workers, she would require more than one instrument to achieve her objective. In particular, non-linear tax instruments could then help to realize the distributional aims. The policy implications of such more comprehensive analysis rely heavily on the exact specification of the social planner's objective function and such an investigation is clearly beyond the scope of the present paper.

In sum, it occurs to us that interesting consequences arise from social preferences (Thorstein 
Veblen) in imperfectly competitive labor markets (Joan Robinson) with respect to wages and employment, and that these call for quite notable modifications on how to think about the role of minimum wages (George J. Stigler) and other tools of government interventions, such as taxes and subsidies.

\section{Appendix}

\section{Wage effect for Example 2:}

Aggregate labor supply (for $c=c^{r}=L^{m}$ ) follows from (21). Differentiating, we obtain:

$$
\begin{gathered}
z_{w}=1 \\
z_{L}=-m(\gamma(1-\beta)+\beta) A L^{m(\gamma(1-\beta)+\beta)-1}<0 \\
z_{\gamma}=-A L^{m(\gamma(1-\beta)+\beta)} \ln (L) m(1-\beta)>0 \text { for } L>1
\end{gathered}
$$

From the optimality condition for the firm (23) we get

$$
\begin{gathered}
b_{w}=-\frac{1+\epsilon}{\epsilon}<0 \\
b_{L}=m(m-1) L^{m-2}<0 \\
b_{\gamma}=w \frac{\epsilon_{\gamma}}{\epsilon^{2}}>0 .
\end{gathered}
$$

We want to determine the sign of (24). After inserting terms we get for the determinant

$$
\begin{gathered}
z_{w} b_{L}-b_{w} z_{L}= \\
=m(m-1) L^{m-2}-\left(\frac{1+\epsilon}{\epsilon}\right)\left(m(\gamma(1-\beta)+\beta) A L^{m(\gamma(1-\beta)+\beta)-1}\right)<0 .
\end{gathered}
$$


Furthermore, the numerator can be written as

$$
\begin{gathered}
-z_{\gamma} b_{L}+b_{\gamma} z_{L}= \\
=\left(A L^{m(\gamma(1-\beta)+\beta)} \ln (L) m(1-\beta)\right) m(m-1) L^{m-2}-w \frac{\epsilon_{\gamma}}{\epsilon^{2}}\left(m(\gamma(1-\beta)+\beta) A L^{m(\gamma(1-\beta)+\beta)-1}\right) .
\end{gathered}
$$

Substitution of elasticities and making use of $z=0$ yields after simplifying terms

$$
\begin{gathered}
-z_{\gamma} b_{L}+b_{\gamma} z_{L}= \\
=m(1-\beta)\left(\left(A L^{m(\gamma(1-\beta)+\beta)+m-2} \ln (L)\right) m(m-1)+\left(m(\gamma(1-\beta)+\beta) A^{2} L^{2 m(\gamma(1-\beta)+\beta)-1}\right)\right) .
\end{gathered}
$$

For this expression to become negative (so that $\frac{d w}{d \gamma}>0$ ) we need to have

$$
m A L^{m(\gamma(1-\beta)+\beta)+m-2}\left(\ln (L)(m-1)+(\gamma(1-\beta)+\beta) A L^{m(\gamma(1-\beta)+\beta)-m+1}\right)>0
$$

which will be fulfilled if the first term in brackets drops out, i.e. for $m \rightarrow 1$. 


\section{References}

Alpizar, F., F. Carlsson, and O. Johansson-Stenman (2005): "How much do we care about absolute versus relative income and consumption?" Journal of Economic Behavior and Organization, 56, 405-421.

Alvarez-Cuadrado, F. (2007): "Envy, leisure, and restrictions on working hours," Canadian Journal of Economics/Revue canadienne d'économique, 40, 1286-1310.

Alvarez-Cuadrado, F., J. M. Casado, and J. M. Labeaga (2016): "Envy and habits: panel data estimates of interdependent preferences," Oxford Bulletin of Economics and Statistics, 78, 443-469.

Aronsson, T. and O. Johansson-Stenman (2008): "When the Joneses' consumption hurts: Optimal public good provision and nonlinear income taxation," Journal of Public Economics, 92, 986-997.

(2010): "Positional concerns in an OLG model: Optimal labor and capital income taxation," International Economic Review, 51, 1071-1095.

(2013): "Conspicuous leisure: Optimal income taxation when both relative consumption and relative leisure matter," The Scandinavian Journal of Economics, 115, 155-175.

(2014): "Positional preferences in time and space: Optimal income taxation with dynamic social comparisons," Journal of Economic Behavior and Organization, 101, 1-23.

_ (2015): "Keeping up with the Joneses, the Smiths and the Tanakas: On international tax coordination and social comparisons," Journal of Public Economics, 131, 71-86.

(2018): "Paternalism against Veblen: Optimal taxation and non-respected preferences for social comparisons," American Economic Journal: Economic Policy, 10, 39-76.

Aronsson, T., O. Johansson-Stenman, and R. Wendner (2019): "Charity, status, and optimal taxation: Welfarist and paternalist approaches," Available at SSRN 3375109. 
Autor, D., D. Dorn, L. F. Katz, C. Patterson, and J. Van Reenen (2017): "Concentrating on the fall of the labor share," American Economic Review: Papers and Proceedings, $107,180-85$.

Azar, J. A., I. Marinescu, M. I. Steinbaum, And B. Taska (2018): "Concentration in US labor markets: Evidence from online vacancy data," National Bureau of Economic Research, Working Paper 24395.

Blanchflower, D. G. And A. J. Oswald (2004): "Well-being over time in Britain and the USA," Journal of Public Economics, 88, 1359-1386.

Boal, W. M. And M. R. Ransom (1997): "Monopsony in the labor market," Journal of Economic Literature, 35, 86-112.

Boskin, M. J. And E. Sheshinski (1978): "Optimal redistributive taxation when individual welfare depends upon relative income," The Quarterly Journal of Economics, 589-601.

Bowles, S. AND Y. PARK (2005): "Emulation, inequality, and work hours: Was Thorsten Veblen right?" The Economic Journal, 115, F379-F412.

Cahuc, P. and G. Laroque (2014): "Optimal taxation and monopsonistic labor market: does monopsony justify the minimum wage?" Journal of Public Economic Theory, 16, 259273.

Carroll, C. D. (2000): "Solving consumption models with multiplicative habits," Economics Letters, 68, 67-77.

Chang, J.-J., C.-Y. LiU, And W.-N. Wang (2018): "Conspicuous consumption and trade unionism," Journal of Macroeconomics, 57, 350-366.

Choudhary, M. A. And P. Levine (2006): "Idle worship," Economics Letters, 90, 77-83.

Clark, A. E. And A. J. Oswald (1996): "Satisfaction and comparison income," Journal of Public Economics, 61, 359-381. 
- (1998): "Comparison-concave utility and following behaviour in social and economic settings," Journal of Public Economics, 70, 133-155.

Clark, A. E., C. Senik, And K. Yamada (2017): "When experienced and decision utility concur: The case of income comparisons," Journal of Behavioral and Experimental Economics, $70,1-9$.

Corneo, G. (2002): "The efficient side of progressive income taxation," European Economic Review, 46, 1359-1368.

DANZiger, L. (2010): "Endogenous monopsony and the perverse effect of the minimum wage in small firms," Labour Economics, 17, 224-229.

Desiraju, R. And D. E. M. Sappington (2007): "Equity and adverse selection," Journal of Economics and Management Strategy, 16, 285-318.

DodDs, S. (2012): "Redistributive taxation with heterogeneous relative consumption concerns," Canadian Journal of Economics/Revue canadienne d'économique, 45, 220-246.

Dube, A., J. Jacobs, S. Naidu, And S. Suri (2020): "Monopsony in online labor markets," Forthcoming in American Economic Review: Insights.

DuesenberRY, J. S. (1949): Income, saving, and the theory of consumer behavior, Harvard University Press.

Dupor, B. And W.-F. LiU (2003): "Jealousy and equilibrium overconsumption," The American Economic Review, 93, 423-428.

Eckerstorfer, P. (2014): "Relative consumption concerns and the optimal tax mix," Journal of Public Economic Theory, 16, 936-958.

Eckerstorfer, P. And R. Wendner (2013): "Asymmetric and non-atmospheric consumption externalities, and efficient consumption taxation," Journal of Public Economics, 106, $42-56$. 
Ferrer-i Carbonell, A. (2005): "Income and well-being: an empirical analysis of the comparison income effect," Journal of Public Economics, 89, 997-1019.

FRANK, R. H. (1984): "Are workers paid their marginal products?" The American Economic Review, 74, 549-571.

_ (2008): "Should public policy respond to positional externalities?" Journal of Public Economics, 92, 1777-1786.

GALI, J. (1994): "Keeping up with the Joneses: Consumption externalities, portfolio choice, and asset prices," Journal of Money, Credit and Banking, 26, 1-8.

Goerke, L. And I. Hillesheim (2013): "Relative consumption, working time, and trade unions," Labour Economics, 24, 170-179.

Goerke, L. And M. Neugart (2017): "Social comparisons in oligopsony," Journal of Economic Behavior and Organization, 141, 196-209.

Goerke, L. And M. Pannenberg (2015): "Direct evidence for income comparisons and subjective well-being across reference groups," Economics Letters, 137, 95-101.

Gómez, M. A. (2008): "Consumption and leisure externalities, economic growth and equilibrium efficiency," Scottish Journal of Political Economy, 55, 227-249.

Grodner, A., T. J. Kniesner, And J. A. Bishop (2011): "Social interactions in the labor market," Foundations and Trends® in Microeconomics, 6, 265-366.

Guo, J.-T. (2005): "Tax policy under keeping up with the Joneses and imperfect competition," Annals of Economics and Finance, 6, 25-36.

Hirsch, B., E. J. Jahn, And C. Schnabel (2018): "Do employers have more monopsony power in slack labor markets?" Industrial and Labor Relations Review, 71, 676-704.

Ireland, N. J. (1998): "Status-seeking, income taxation and efficiency," Journal of Public Economics, 70, 99-113. 
- (2001): "Optimal income tax in the presence of status effects," Journal of Public Economics, 81, 193-212.

Keynes, J. M. (1936): The general theory of interest, employment and money, London: Macmillan.

LiU, W.-F. And S. J. TuRnovsky (2005): "Consumption externalities, production externalities, and long-run macroeconomic efficiency," Journal of Public Economics, 89, 1097-1129.

LJungQvist, L. And H. Uhlig (2000): "Tax policy and aggregate demand management under catching up with the Joneses," The American Economic Review, 90, 356-366.

LutTmer, E. F. (2005): "Neighbors as negatives: Relative earnings and well-being," The Quarterly Journal of Economics, 120, 963-1002.

Manning, A. (2003): Monopsony in motion: Imperfect competition in labor markets, Princeton University Press.

- (2004): "Monopsony and the efficiency of labour market interventions," Labour Economics, 11, 145-163.

- (2011): "Imperfect competition in the labor market," in Handbook of Labor Economics, ed. by D. Card and O. Ashenfelter, Elsevier, vol. 4b, 973-1041.

Marx, K. (1977): "Wage Labour and Capital (1849)," in Collected Works, ed. by K. Marx and F. Engels, Moscow: Progress Publishers.

Mauleon, A., V. Vannetelbosch, And C. Vergari (2014): "Unions' relative concerns and strikes in wage bargaining," Bulletin of Economic Research, 66, 374-383.

Micheletto, L. (2011): "Optimal nonlinear redistributive taxation and public good provision in an economy with Veblen effects," Journal of Public Economic Theory, 13, 71-96.

Mujcic, R. AND P. FriJters (2013): "Economic choices and status: measuring preferences for income rank," Oxford Economic Papers, 65, 47-73. 
- (2015): "Conspicuous consumption, conspicuous health, and optimal taxation," Journal of Economic Behavior and Organization, 111, 59-70.

Nelson, P. (1973): "The elasticity of labor supply to the individual firm," Econometrica, $853-866$.

Neumark, D. And A. Postlewaite (1998): "Relative income concerns and the rise in married women's employment," Journal of Public Economics, 70, 157-183.

PARK, Y. (2010): "The second paycheck to keep up with the Joneses: Relative income concerns and labor market decisions of married women," Eastern Economic Journal, 36, 255-276.

PÉRez-Asenjo, E. (2011): "If happiness is relative, against whom do we compare ourselves? Implications for labour supply," Journal of Population Economics, 24, 1411-1442.

Persson, M. (1995): "Why are taxes so high in egalitarian societies?" The Scandinavian Journal of Economics, 569-580.

Pigou, A. C. (1903): "Some remarks on utility," The Economic Journal, 13, 58-68.

Robinson, J. (1933): The economics of imperfect competition, London: Macmillan, reprint 1950.

SAlop, S. C. (1979): "Monopolistic competition with outside goods," The Bell Journal of Economics, 10, 141-156.

SAndmo, A. (1994): "Monopsonistic wage discrimination, incentives and efficiency," Labour Economics, 1, 151-170.

ScHor, J. B. (1991): The overworked American: The unexpected decline of leisure, New York: Basic Books.

SEnIK, C. (2009): "Direct evidence on income comparisons and their welfare effects," Journal of Economic Behavior and Organization, 72, 408-424.

Smith, A. (1776): An Inquiry Into The Nature And Causes Of The Wealth of Nations, Basil. 
Sokolova, A. And T. Sorensen (2018): "Monopsony in labor markets: a meta-analysis," IZA Discussion Paper No. 11966.

Stigler, G. J. (1946): "The economics of minimum wage legislation," The American Economic Review, 36, 358-365.

_ (1963): "Reviewed Work(s): Economic Philosophy by Joan Robinson," Journal of Political Economy, 71, 192-193.

Strobl, E. And F. WALsh (2007): "Dealing with monopsony power: Employment subsidies vs. minimum wages," Economics Letters, 94, 83-89.

Sullivan, D. (1989): "Monopsony power in the market for nurses," Journal of Law and Economics, 32, S135-S178.

Veblen, T. (1899): The theory of the leisure class, A Penn State Electronic Classics Series Publication, published in 2003.

von Siemens, F. A. (2010): "Heterogeneous social preferences, screening, and employment contracts," Oxford Economic Papers, 63, 499-522.

(2012): "Social preferences, sorting, and competition," The Scandinavian Journal of Economics, 114, 780-807.

Wendner, R. (2014): "Ramsey, Pigou, heterogeneous agents, and nonatmospheric consumption externalities," Journal of Public Economic Theory, 16, 491-521.

Wendner, R. And L. H. Goulder (2008): "Status effects, public goods provision, and excess burden," Journal of Public Economics, 92, 1968-1985.

Woo, W. C. (2011): "Status and welfare under monopolistic competition," Social Choice and Welfare, 36, 227-239.

(2016): "Status goods and market powers," German Economic Review, 17, 26-35. 


\section{IAAEU Discussion Paper Series in Economics}

01/2012 Relative Consumption Concerns or Non-Monotonic Preferences?

Inga Hillesheim and Mario Mechtel

02/2012 Profit Sharing and Relative Consumption

Laszlo Goerke

[published as: Goerke, L. (2013). Profit Sharing and Relative Consumption. Economics Letters $118(1), 167-169$.

03/2012 Conspicuous Consumption and Communism: Evidence from East and West Germany Tim Friehe and Mario Mechtel

[published as: Friehe, T. and M. Mechtel (2014). Conspicuous Consumption and Political Regimes: Evidence from East and West Germany. European Economic Review 67, 62-81.]

04/2012 Unemployment Benefits as Redistribution Scheme for Trade Gains - A Positive Analysis

Marco de Pinto

[published as: de Pinto, M. (2013). International Trade and Unemployment: On the Redistribution of Trade Gains when Firms Matter, Physica-Verlag (Springer), Berlin.]

05/2012 Failure of Ad Valorem and Specific Tax: Equivalence under Uncertainty

Laszlo Goerke, Frederik Herzberg and Thorsten Upmann

[revised version published as: Goerke, L., F. Herzberg and T. Upmann (2014). Failure of Ad Valorem and Specific Tax Equivalence under Uncertainty. International Journal of Economic Theory 10 (4), 387-402.]

06/2012 The Redistribution of Trade Gains and the Equity-Efficiency Trade-Off Marco de Pinto

[published as: de Pinto, M. (2013). International Trade and Unemployment: On the Redistribution of Trade Gains when Firms Matter, Physica-Verlag (Springer), Berlin.]

07/2012 Trade Union Membership and Sickness Absence: Evidence from a Sick Pay Reform Laszlo Goerke and Markus Pannenberg

[published as: Goerke, L. and M. Pannenberg (2015). Trade Union Membership and Sickness Absence: Evidence from a Sick Pay Reform. Labour Economics 33, 13-25.]

08/2012 Risk-Sorting and Preference for Team Piece Rates

Agnes Bäker and Vanessa Mertins

[published as: Bäker, A. and V. Mertins (2013). Risk-Sorting and Preference for Team Piece

Rates. Journal of Economic Psychology 34, 285-300.]

09/2012 Union Wage Setting and International Trade

Hartmut Egger and Daniel Etzel

[published as: Egger, H. and D. Etzel (2014). Union wage-setting and international trade with footloose capital. Regional Science and Urban Economics 48, 56-67.] 
10/2012 How Much Do Others Matter? Explaining Positional Concerns for Different Goods and Personal Characteristics

Inga Hillesheim and Mario Mechtel

[published as: Hillesheim, I. and M. Mechtel (2013). How Much Do Others Matter? Explaining Positional Concerns for Different Goods and Personal Characteristics. Journal of Economic Psychology 34, 61-77.]

11/2012 Benefit Morale and Cross-Country Diversity in Sick Pay Entitlements Daniel Arnold

[published as: Arnold, D. (2013). Benefit Morale and Cross-Country Diversity in Sick Pay Entitlements. Kyklos 66 (1), 27-45.]

01/2013 Relative Consumption and Tax Evasion

Laszlo Goerke

[published as: Goerke, L. (2013). Relative Consumption and Tax Evasion. Journal of Economic Behavior \& Organization 87, 52-65.]

02/2013 Variants of the Monoamine Oxidase A Gene (MAOA) Predict Free-riding Behavior in Women in a Strategic Public Goods Experiment

Vanessa Mertins, Andrea B. Schote and Jobst Meyer

[published as: Mertins, V., A.B. Schote and J. Meyer (2013). Variants of the Monoamine Oxidase A Gene (MAOA) Predict Free-riding Behavior in Women in a Strategic Public Goods Experiment. Journal of Neuroscience, Psychology, and Economics 6 (2), 97-114.]

03/2013 Direct Evidence on Income Comparisons and Subjective Well-Being Laszlo Goerke and Markus Pannenberg

04/2013 Flexibilisation without Hesitation? Temporary Contracts and Workers' Satisfaction Adrian Chadi and Clemens Hetschko

[published as: Chadi, A. and C. Hetschko (2016). Flexibilisation without Hesitation? Temporary Contracts and Job Satisfaction. Oxford Economic Papers 68(1), 217-237.]

05/2013 Structural and Cyclical Effects of Tax Progression

Jana Kremer and Nikolai Stähler

[published as: Kremer, J. and N. Stähler (2016). Structural and Cyclical Effects of Tax

Progression. FinanzArchiv: Public Finance Analysis 72 (1), 41-73.]

06/2013 Regional Unemployment and Norm-Induced Effects on Life Satisfaction

Adrian Chadi

[published as: Chadi, A. (2014). Regional Unemployment and Norm-Induced Effects on Life Satisfaction. Empirical Economics 46 (3), 1111-1141.]

07/2013 Third Person Effects in Interview Responses on Life Satisfaction

Adrian Chadi

[published as: Chadi, A. (2013). Third Person Effects in Interview Responses on Life Satisfaction. Journal of Applied Social Science Studies (Schmollers Jahrbuch) 133 (2), 323-333.]

08/2013 The Role of Task Meaning on Output in Groups: Experimental Evidence Agnes Bäker and Mario Mechtel [published as: Bäker, A. and M. Mechtel (2018). The Role of Task Meaning on Output in Groups: Experimental Evidence. Managerial and Decision Economics 39 (2), 131-141.] 
09/2013 Gender Differences in Responsiveness to a Homo Economicus Prime in the

Gift-Exchange Game

Vanessa Mertins and Susanne Warning

10/2013 Relative Consumption, Working Time, and Trade Unions

Laszlo Goerke and Inga Hillesheim

[published as: Goerke, L. and I. Hillesheim (2013). Relative Consumption, Working Time, and

Trade Unions. Labour Economics 24, 170-179.]

11/2013 The Role of Interviewer Encounters in Panel Responses on Life Satisfaction

Adrian Chadi

[published as: Chadi, A. (2013). The Role of Interviewer Encounters in Panel Responses on Life Satisfaction. Economics Letters 121 (3), 550-554.]

12/2013 It's the Occupation, Stupid! Explaining Candidates' Success in Low-Information

Elections

Mario Mechtel

[published as: Mechtel, M. (2014). It's the occupation, stupid! Explaining candidates' success in low-information elections. European Journal of Political Economy 33, 53-70.]

13/2013 Do Overconfident Workers Cooperate Less? The Relationship between

Overconfidence and Cooperation in Team Production

Vanessa Mertins and Wolfgang Hoffeld

[published as: Mertins, V. and W. Hoffeld (2015). Do Overconfident Workers Cooperate Less?

The Relationship between Overconfidence and Cooperation in Team Production. Managerial and Decision Economics 36 (4), 265-274.]

01/2014 Income Tax Buyouts and Income Tax Evasion

Laszlo Goerke

[published as: Goerke, L. (2015). Income Tax Buyouts and Income Tax Evasion. International Tax and Public Finance 22 (1), 120-143.]

02/2014 Family Employees and Absenteeism

Jörn Block, Laszlo Goerke, José María Millán and Concepción Román

[published as: Block, J., L. Goerke, J.M. Millán and C. Román (2014). Family Employees and

Absenteeism. Economics Letters 123 (1), 94-99.]

03/2014 Dissatisfied with Life or with Being Interviewed? Happiness and Motivation to Participate in a Survey

Adrian Chadi

[published as: Chadi, A. (2019). Dissatisfied with Life or with Being Interviewed? Happiness and Motivation to Participate in a Survey. Social Choice and Welfare 53(3), 519-553.]

04/2014 Gambling to Leapfrog in Status?

Tim Friehe and Mario Mechtel

[published as: Friehe, T. and M. Mechtel (2017). Gambling to Leapfrog in Status. Review of

Economics of the Household 15 (4), 1291-1319.]

05/2014 The Magic of the New: How Job Changes Affect Job Satisfaction

Adrian Chadi and Clemens Hetschko

[published as: Chadi, A. and C. Hetschko (2018). The Magic of the New: How Job Changes Affect Job Satisfaction. Journal of Economics \& Management Strategy 27(1), 23-39.] 
06/2014 The Labor Market Effects of Trade Unions - Layard Meets Melitz Marco de Pinto and Jochen Michaelis

[published as: de Pinto, M. and J. Michaelis (2016). The Labor Market Effects of Trade Unions in an Open Economy - Layard Meets Melitz. International Economics and Economic Policy 13(2), 223-232.]

07/2014 Workers' Participation in Wage Setting and Opportunistic Behavior: Evidence from a Gift-Exchange Experiment

Jörg Franke, Ruslan Gurtoviy and Vanessa Mertins

[published as: Franke, J.; R. Gurtnoviy and V. Mertins (2016). Workers' Participation in Wage Setting: A Gift-Exchange Experiment. Journal of Economic Psychology 56, 151-162.]

08/2014 Wage Delegation in the Field

Sabrina Jeworrek and Vanessa Mertins

[published as: Jeworrek, S. and V. Mertins (2019). Wage Delegation in the Field. Journal of Economics and Management Strategy 28, 656-669.]

09/2014 Tax Evasion by Individuals

Laszlo Goerke

[published as: Goerke, L. (2015). Tax Evasion by Individuals. Encyclopedia of Law and Economics: Springer Reference.]

10/2014 Sickness Absence and Works Councils

Daniel Arnold, Tobias Brändle and Laszlo Goerke

[published as: Arnold, D., T. Brändle and L. Goerke (2018). Sickness Absence and Works

Councils - Evidence from German Individual and Linked Employer-Employee Data. Industrial Relations: A Journal of Economy and Society 57(2), 260-295.]

11/2014 Positional Income Concerns: Prevalence and Relationship with Personality and Economic Preferences

Tim Friehe, Mario Mechtel and Markus Pannenberg

[published as: Friehe, T., M. Mechtel and M. Pannenberg (2018). Positional Income Concerns and Personality: Evidence from Germany. Applied Economics Letters 24(14), 1024-1028.]

12/2014 Unionization, Information Asymmetry and the De-location of Firms

\section{Marco de Pinto and Jörg Lingens}

[forthcoming as: de Pinto, M. and J. Lingens. Unionization, Information Asymmetry and the Delocation of Firms. Canadian Journal of Economics.]

01/2015 The One Constant: A Causal Effect of Collective Bargaining on Employment Growth? Evidence from German Linked-Employer-Employee Data

Tobias Brändle and Laszlo Goerke

[published as: Brändle, T. and L. Goerke (2018). The One Constant: A Causal Effect of Collective Bargaining on Employment Growth? Evidence from German Linked-Employer-Employee Data. Scottish Journal of Political Economy 65(5), 445-478.]

02/2015 How Job Changes Affect People's Lives - Evidence from Subjective Well-being Data Adrian Chadi and Clemens Hetschko

03/2015 Concerns about the Euro and Happiness in Germany during Times of Crisis Adrian Chadi

[published as: Chadi, A. (2015). Concerns about the Euro and Happiness in Germany during Times of Crisis. European Journal of Political Economy 40, 126-146.] 
04/2015 Missing at Work - Sickness-related Absence and Subsequent Job Mobility Adrian Chadi and Laszlo Goerke

[published as: Chadi, A. and L. Goerke (2018). Missing at Work - Sickness-related Absence and Subsequent Career Events. Journal of Economic Behavior \& Organization 153, 153-176.]

05/2015 Social Identity and Social Free-Riding

Mark Bernard, Florian Hett and Mario Mechtel

[published as: Bernard, M., F. Hett and M. Mechtel (2016). Social Identity and Social FreeRiding. European Economic Review 90(11), 4-17.]

06/2015 Peer Settings Induce Cheating on Task Performance

Agnes Bäker and Mario Mechtel

[published as: Bäker, A. and M. Mechtel (2019). The Impact of Peer Presence on Cheating. Economic Inquiry 57(2), 792-812.]

07/2015 The Protestant Fiscal Ethic: Religious Confession and Euro Skepticism in Germany Adrian Chadi and Matthias Krapf

[published as: Chadi, A. and M. Krapf (2017). The Protestant Fiscal Ethic: Religious Confession and Euro Skepticism in Germany. Economic Inquiry 55(4), 1813-1832.]

08/2015 Firm-level versus Sector-level Trade Unions - The Role of Rent-Sharing Motives

Marco de Pinto

[published as: de Pinto, M. (2019). The Impact of Unionization Structures with Heterogeneous Firms and Rent-Sharing Motives. Scandinavian Journal of Economics 121(1), 298-325.]

09/2015 Direct Evidence for Income Comparisons and Subjective Well-Being across Reference Groups

Laszlo Goerke and Markus Pannenberg

[published as: Goerke, L. and M. Pannenberg (2015). Direct Evidence for Income Comparisons and Subjective Well-Being across Reference Groups. Economics Letters 137, 95-101.]

10/2015 Leadership and persistency in spontaneous dishonesty

Susanne Braun and Lars Hornuf

11/2015 How are Work-related Characteristics Linked to Sickness Absence and Presenteeism? Theory and Data -

Daniel Arnold and Marco de Pinto

[published as: Arnold, D. and M. de Pinto (2015). How are Work-related Characteristics Linked to Sickness Absence and Presenteeism? - Theory and Data. Journal of Applied Social Science Studies (Schmollers Jahrbuch) 135(4), 465-498.]

01/2016 Paid Vacation Use: The Role of Works Councils

Laszlo Goerke and Sabrina Jeworrek

[forthcoming as: Goerke, L. and S. Jeworrek. Paid Vacation Use: The Role of Works Councils. Economic and Industrial Democracy.]

02/2016 Identification of Attrition Bias Using Different Types of Panel Refreshments Adrian Chadi 
03/2016 Welfare-enhancing Trade Unions in an Oligopoly with Excessive Entry Marco de Pinto and Laszlo Goerke

[published as: de Pinto, M. and L. Goerke (2020). Welfare-enhancing Trade Unions in an Oligopoly with Excessive Entry. The Manchester School 88(1), 60-90.]

04/2016 Sick Pay Reforms and Health Status in a Unionised Labour Market Laszlo Goerke

[published as: Goerke, L. (2017). Sick Pay Reforms and Health Status in a Unionised Labour Market. Scottish Journal of Political Economy 64(2), 115-142.]

05/2016 Tax Evasion in a Cournot Oligopoly with Endogenous Entry

Laszlo Goerke

[published as: Goerke, L. (2017). Tax Evasion in a Cournot Oligopoly with Endogenous Entry. International Tax and Public Finance 24 (5), 754-779.]

06/2016 The Emergence of the Global Fintech Market: Economic and Technological Determinants

Christian Haddad and Lars Hornuf

[published as: Haddad, C. and L. Hornuf (2019). The Emergence of the Global Fintech Market: Economic and Technological Determinants. Small Business Economics 53(1), 81-105.]

01/2017 The Impact of Unionization Costs when Firm-selection Matters

Marco de Pinto and Jörg Lingens

[published as: de Pinto, M. and J. Lingens (2019). The Impact of Unionization Costs when Firmselection Matters. Labour Economics 60, 50-63.]

02/2017 Can Television Reduce Xenophobia? The Case of East Germany Lars Hornuf and Marc Oliver Rieger

03/2017 The Effect of Cigarette Taxes During Pregnancy on Educational Outcomes of the Next generation

Sonja Settele and Reyn van Ewijk

04/2017 Social Comparisons in Oligopsony

Laszlo Goerke and Michael Neugart

[published as: Goerke, L. and M. Neugart (2017). Social Comparisons in Oligopsony. Journal of Economic Bahavior \& Organization 141, 196-209.]

05/2017 Young, Gifted and Lazy? The Role of Ability and Labor Market Prospects in Student Effort Decisions

Adrian Chadi, Marco de Pinto and Gabriel Schultze

[published as: Chadi, A., M. de Pinto and G. Schultze (2019). Young, Gifted and Lazy? The Role of Ability and Labor Market Prospects in Student Effort Decisions. Economics of Education Review 72, 66-79.]

06/2017 Income or Leisure? On the Hidden Benefits of (Un-)Employment Adrian Chadi and Clemens Hetschko

07/2017 Does Commuting Matter to Subjective Well-Being?

Olga Lorenz

[published as: Lorenz, O. (2018). Does Commuting Matter to Subjective Well-Being?. Journal of Transport Geography 66, 180-199.] 
08/2017 Minimum Wages and Vocational Training Incentives in Germany Kim Leonie Kellermann

09/2017 There Is No Place like Work: Evidence on Health and Labor Market Behavior from Changing Weather Conditions

Adrian Chadi

10/2017 Firm Selection and the Role of Union Heterogeneity Marco de Pinto and Jochen Michaelis

[published as: de Pinto, M. and J. Michaelis (2019). The Labor Market Effects of Trade Union Heterogeneity. Economic Modelling 78, 60-72.]

11/2017 Employment Protection Legislation and Mismatch: Evidence from a Reform Fabio Berton, Francesco Devicienti and Sara Grubanov-Boskovic

12/2017 Commuting and Sickness Absence

Laszlo Goerke and Olga Lorenz

01/2018 Wage Inequality and Structural Change Joanna Tyrowicz and Magdalena Smyk

[published as: Tyrowicz, J. and M. Smyk (2018). Wage Inequality and Structural Change. Social Indicators Research 141(2), 503-538.]

02/2018 Labor Reallocation and Demographics Joanna Tyrowicz and Lucas van der Velde [published as: Tyrowicz, J. and L. van der Velde (2018). Labor Reallocation and Demographics. Journal of Comparative Economics 46(1), 381-412.]

03/2018 Identifying Age Penalty in Women's Wages: New Method and Evidence from Germany 1984-2014

Joanna Tyrowicz, Lucas van der Velde and Irene van Staveren

[published as: Tyrowicz, J., L. van der Velde and I. van Staveren (2018). Does Age Exacerbate the Gender-Wage Gap? New Method and Evidence from Germany, 1984-2014. Feminist Economics 24(4), 108-130.]

04/2018 On Welfare Effects of Increasing Retirement Age

Krzysztof Makarski and Joanna Tyrowicz

[published as: Makarski, K. and J. Tyrowicz (2019). On Welfare Effects of Increasing Retirement Age. Journal of Policy Modelling 41(4), 718-746.]

05/2018 A Cautionary Note on the Reliability of the Online Survey Data - the Case of Wage Indicator

Magdalena Smyk, Joanna Tyrowicz and Lucas van der Velde [forthcoming as: Smyk, M., J. Tyrowicz. and L. van der Velde. A Cautionary Note on the Reliability of the Online Survey Data - the Case of Wage Indicator. Sociological Methods and Research.]

06/2018 How (Not) to Make Women Work?

Karolina Goraus, Joanna Tyrowicz and Lucas van der Velde

[published as: Goraus, K., J. Tyrowicz and L. van der Velde (2018). How (Not) to Make Women Work? Social Science Research 75, 154-167.] 
[published as: de Pinto, M. and L. Goerke (2019). Efficiency Wages in a Cournot-Oligopoly, The B.E. Journal of Economic Analysis and Policy 19(4).]

08/2018 Inequality in an OLG Economy with Heterogeneous Cohorts and Pension Systems Joanna Tyrowicz, Krzysztof Makarski and Marcin Bielecki

[published as: Tyrowicz, J., K. Makarski and M. Bielecki (2018). Inequality in an OLG Economy with Heterogeneous Cohorts and Pension Systems. Journal of Economic Inequality 16(4), 583606.]

09/2018 Corporate Social Responsibility and Tax Avoidance Laszlo Goerke [published as: Goerke, L. (2019). Corporate Social Responsibility and Tax Avoidance. Journal of Public Economic Theory 21(2), 310-331.]

10/2018 A Regression Discontinuity Evaluation of Reducing Early Retirement Eligibility in Poland Oliwia Komada, Pawel Strzelecki and Joanna Tyrowicz

[published as: Komada, O., P. Strzeleck and J. Tyrowicz (2019). A Regression Discontinuity Evaluation of Reducing Early Retirement Eligibility in Poland. International Journal of Manpower 40(2), 286-303.]

11/2018 Stigmatization, Liability and Public Enforcement of Law Clemens Buchen, Bruno Deffains and Alberto Palermo

[published as: Buchen, C., B. Deffains and A. Palermo (2019). Stigmatization, Liability and Public Enforcement of Law. Revue d'économie politique 129(2), 239-259.]

12/2018 Sickness Absence and Relative Income Laszlo Goerke [published as: Goerke, L. (2019). Absence from Work, Sick Pay and Positional Consumption Concerns. Labour: Review of Labour Economics and Industrial Relations 33(2), 187-211.]

01/2019 Ostracism in Alliances of Teams and Individuals: Voting, Exclusion, Contribution, and Earnings Stephan Huber, Jochen Model and Silvio Städter

02/2019 Evaluating Welfare and Economic Effects of Raised Fertility Krzysztof Makarski, Joanna Tyrowicz and Magda Malec [forthcoming as: Makarski, K., J. Tyrowicz and M. Malec. Fiscal and Welfare Effects of Raised Fertility in Poland: Overlapping Generations Model Estimates. Population and Development Review.]

03/2019 The Structure and Behavioral Effects of Revealed Social Identity Preferences Florian Hett, Markus Kröll, Mario Mechtel

[forthcoming as: Hett, F., M. Kröll and M. Mechtel. The Structure and Behavioral Effects of Revealed Social Identity Preferences. Economic Journal.]

04/2019 All on board? New Evidence on Board Gender Diversity from a Large Panel of European Firms Joanna Tyrowicz, Siri Terjesen, Jakub Mazurek [forthcoming as: Tyrowicz, J., S. Terjesen and J. Mazurek. All on Board? New Evidence on Board Gender Diversity from a Large Panel of European Firms. European Management Journal.] 
01/2020 Thorstein Veblen, Joan Robinson, and George Stigler (probably) never met: Social Preferences, Monopsony, and Government Intervention Laszlo Goerke, Michael Neugart 